\title{
Water, Sediment, Nutrient, and Pesticide Measurements in an Agricultural Watershed IN ILLINOIS DURING STORM EvenTS
}

\author{
D. K. Borah, M. Bera, S. Shaw
}

\begin{abstract}
Flow and concentrations of suspended sediment, nitrate- $N$, phosphate- $P$, atrazine, and metolachlor were monitored during the spring seasons of 1998 and 1999, primarily during storm events, at a tributary station (Big Ditch) and two main-stem stations (Fisher and Mahomet) of the Upper Sangamon River watershed in east central Illinois. These three stations respectively drain 98, 622, and $932 \mathrm{~km}^{2}$ of mainly agricultural lands. Rainfall data were collected from six newly established raingage stations. The study provides a valuable database to understand some of the complex physical and chemical processes in an east central Illinois watershed and to calibrate, validate, and evaluate mathematical models. Analyses of the limited data from different sampling methods showed consistencies among the methods. The nitrate-N concentrations in Big Ditch during intense storms of 1998 showed inverse relationships with water discharge. Higher goodness-of-fit of the relationships was found within the data for individual months than for the combined set, showing dependence on varying climate, land cover, and management practices during the growing season. The nitrate- $N$ concentrations at each of the three stations during less intense storms in 1999 showed weak positive relationships with water discharge. The total nitrate-N load in Big Ditch generated by the storms of March, May, and June of 1998 was similar to the average annual load, indicating the importance of single-event storms, and therefore their need for close attention. After the intense storm of April 1999, the less intense storms during May and June after long low-flow periods significantly raised the nitrate $-N$ concentrations in all three stations. A similar pattern was noticed in the 1998 observations before each of the major peaks, when the smaller peaks elevated nitrate- $N$ concentrations followed by dilution with the larger peaks. Results of this study show positive relationships between suspended sediment concentration and water discharge for the smaller watershed (Big Ditch); however, no relationships were found in the larger watersheds (Upper Sangamon River at Fisher and Mahomet). Observed data at each of the stations showed positive relationships of phosphate-P, atrazine, and metolachlor concentrations with water discharge.
\end{abstract}

Keywords. Agrochemical, Rainfall events, Sampling methodologies, Water quality, Watershed monitoring.

$\mathrm{F}$ looding, upland soil and streambank erosion, sedimentation, and contamination of water from agricultural chemicals are critical environmental, social, and economic problems in Illinois, in the U.S., and throughout the world. For example, damages from the 1993 flood in the upper Mississippi River were extensive ( $\$ 12$ to $\$ 16$ billion), with unquantifiable impacts on the health and well-being of the U.S. Midwestern population (IFMRC, 1994).

Many Midwestern U.S. streams and rivers draining agricultural watersheds have elevated concentrations of nitrate-nitrogen (nitrate-N) (Smith et al., 1993; Goolsby et

Article was submitted for review in June 2002; approved for publication by the Soil \& Water Division of ASAE in January 2003.

The views expressed in this article are solely those of the authors and not necessarily of their affiliated and funding agencies. Mention of products or commercial services does not reflect endorsement by the authors and their affiliated and funding agencies.

The authors are Deva K. Borah, ASAE Member Engineer, Research Hydrologic Engineer, Maitreyee Bera, Supportive Scientist, and Susan Shaw, former Associate Supportive Scientist; Illinois State Water Survey, Champaign, Illinois. Corresponding author: D. K. Borah, Illinois State Water Survey, 2204 Griffith Drive, Champaign, IL 61820; phone: 217-244-8856; fax: 217-333-2304; e-mail: borah@uiuc.edu. al., 1999). Forty percent of the rivers, $51 \%$ of the lakes, and $57 \%$ of the estuaries surveyed in the U.S. in 1994 (Doering et al., 1999) were found to be impaired by nutrient enrichment and nonpoint-source pollution; agriculture was identified as the most widespread source of water pollution. In Illinois, some drinking water supplies, such as that of Decatur (Demissie et al., 1996), Pontiac (Keefer et al., 1996), and Georgetown (Mitchell et al., 2000), periodically exceed the drinking water standard of $10 \mathrm{mg} / \mathrm{L}$ of nitrate- $\mathrm{N}$ that was set to prevent incidence of methemoglobinemia, often referred to as "blue baby" syndrome.

Other drinking water sources, such as Lake Springfield, require expensive water treatments when they periodically exceed the $3 \mu \mathrm{g} / \mathrm{L}$ maximum concentration level (MCL) for atrazine, a commonly used herbicide (Luepke, 1996). Lake Decatur (Fitzpatrick et al., 1987), Lake Springfield (Fitzpatrick et al., 1985), and Peoria Lake (Demissie et al., 1988) in Illinois are examples of serious lake sedimentation reducing water supply capacity of the former two and filling the navigation channel of the latter. Court Creek and its major tributaries above Dahinda, Illinois (Roseboom et al., 1982) are examples of serious streambank erosion.

Understanding and dealing with the above complex hydrologic, soil erosion, and sediment and contaminant transport processes and the associated problems have been a

Transactions of the ASAE 
challenge for scientists and engineers, especially due to the spatial and temporal variability of these processes within a watershed. Field monitoring and mathematical (computer) modeling, which are interdependent, are the major approaches used to understand these complex processes and help find solutions to the associated nonpoint-source pollution problems. The models help in evaluating and selecting from alternative land-use and best management practice (BMP) scenarios, implementation of which may reduce the damaging effects of storm water runoff and the accompanying nonpoint-source pollution on water bodies and the landscape. Monitoring studies and the data from those studies are critical in the development and evaluation of computer models.

Most of the watershed-scale monitoring, as reviewed and discussed below, involves continuous long-term monitoring, which is a valuable source of information and data for understanding the seasonal and yearly patterns of flow, sediment, and nutrients generated within agricultural watersheds. Gentry et al. (1998) and David et al. (1997) showed that heavy rainfall caused brief episodes of high discharges of water, sediment, and agrochemicals that make up a significant fraction of the total annual discharges. Such events could be similar to the catastrophic 1993 flood in the upper Mississippi River. Therefore, detailed monitoring of single-event storms would be useful in understanding the processes occurring during these events. The data generated would be extremely valuable in developing or evaluating models to deal with single-event storms that may be catastrophic.

The primary objective of this study was to monitor and collect data from an agricultural watershed in Illinois during

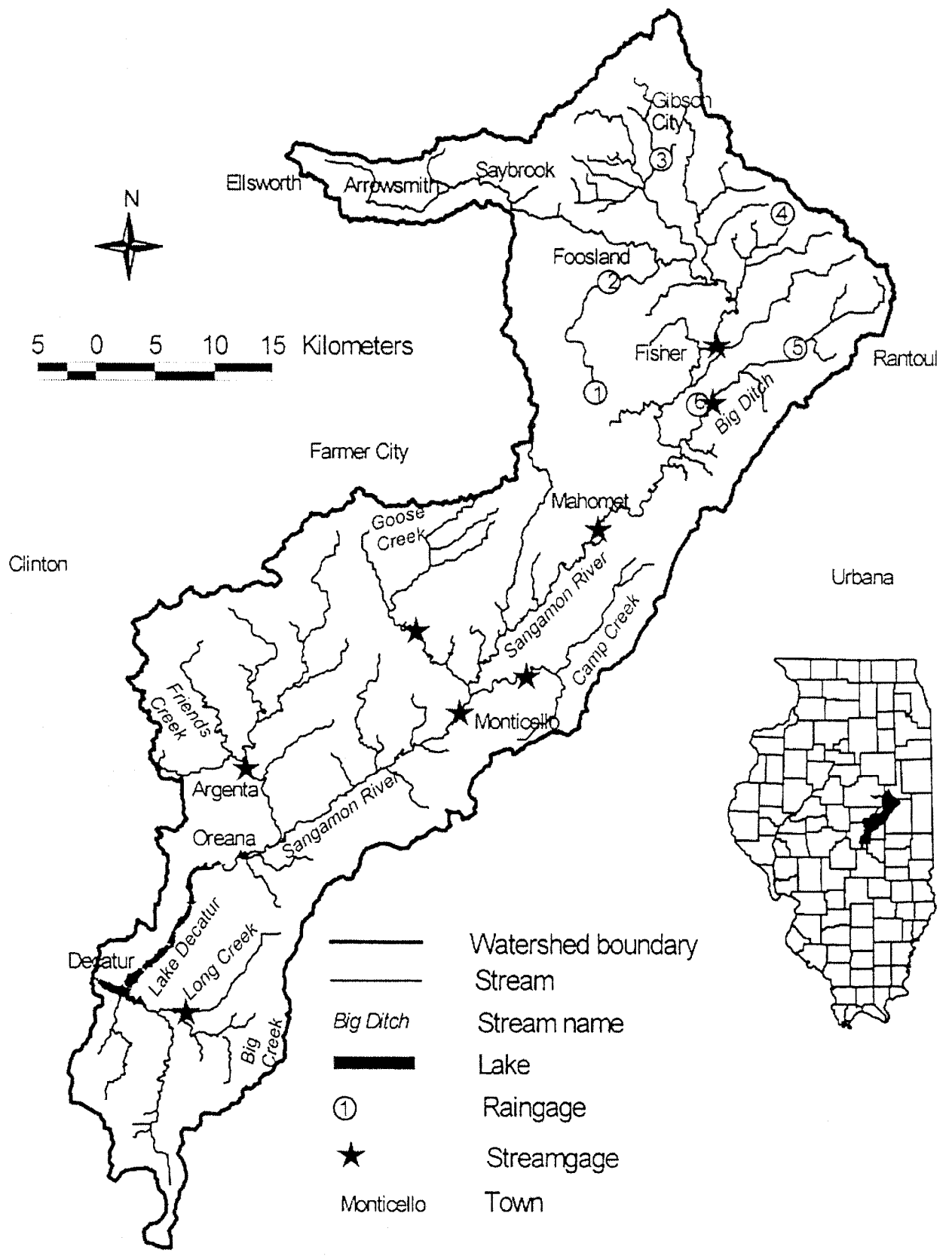

Figure 1. Upper Sangamon River watershed in Illinois draining into Lake Decatur. 
storm events, which could be used to help understand dynamic processes and to test and evaluate nonpoint-source pollution models in Illinois. Flow and concentrations of suspended sediment, nitrate-N, phosphate-P, atrazine, and metolachlor were measured during the 1998 spring storm events at the Big Ditch station (fig. 1), draining a $98 \mathrm{~km}^{2}$ subwatershed of the Upper Sangamon River (Lake Decatur) watershed in Illinois. During 1999, the same types of data, except metolachlor, were collected at Big Ditch and at two other stations (Fisher and Mahomet, draining 622 and $932 \mathrm{~km}^{2}$ of the Lake Decatur watershed, respectively) on the main stem of Sangamon River (fig. 1). Metolachlor was not monitored during 1999 because of budget constraints, and its data were found similar to atrazine during 1998 monitoring. Rainfall data were collected from newly established raingages, one at Big Ditch (station 6 in fig. 1) during 1998 and 1999, and five others located throughout the Upper Sangamon River watershed above Mahomet (stations 1 to 5 in fig. 1) during 1999.

The monitored constituent data were analyzed to confirm consistencies of different sampling methods and to develop relationships between suspended sediment and chemical concentrations with observed flow. These analyses, along with some of the data and data collection methods, are presented and briefly discussed in this article. More details on data and some of the analyses may be found in Borah et al. (1999). The study provides a useful database of continuous rainfall, runoff, sediment, nitrate, phosphorous, atrazine, and metolachlor in an east central Illinois watershed collected during storm events. The data help in understanding some of the complex physical and chemical processes occurring in a watershed and also help in calibration, validation, and evaluation of mathematical models.

The flow, sediment, and phosphate-P data monitored at the Big Ditch station were used to calibrate and validate the hydrologic, sediment, and agrochemical components of the Dynamic Watershed Simulation Model, or DWSM (Borah et al., 2002b). The DWSM generates spatially distributed and time--varying water, sediment, and chemical discharges in a watershed divided into overland planes, channel segments, and reservoir units, resulting from a single rainfall event or from a series of single events. Details of the modeling studies were presented and reported in Borah et al. (1999, 2000, 2001, 2002c) and will be further reported in future publications.

\section{BACKGROUND LITERATURE}

Numerous monitoring studies are reported in the literature. Most of these are field experiments; only a handful are on the watershed scale. Some watershed-scale monitoring studies reported in recent years are reviewed below.

Stone et al. (2000) monitored stream water quality in a $21 \mathrm{~km}^{2}$ watershed in eastern North Carolina. They compared four stream sampling methods: time-composite sampling with continuous flow measurements (TC), flow-proportional sampling with independent measurement of flow (FP), grab sampling with instantaneous flow measurements (IG), and grab sampling for quality assurance/quality control checks using U.S. Geological Survey (USGS) flow measurements (UG). Grab samples are samples collected manually and instantaneously. In that study, grab samples were collected once a week, except for twice-a-month sampling during the December-February period. Flow measurements using the TC and IG methods were highly correlated. The FP method sampled greater flow rates during the sampling period and as a result predicted greater mass loading rates. For all four methods, nitrate-N, ammonia-N, and total Kjeldahl nitrogen (TKN) concentrations were not correlated to stream flow.

Kramer et al. (1999) reported monitoring of four fieldscale (two paired) watersheds, 30 to 60 ha, near Treynor, Iowa. After analyzing 30 years of precipitation, runoff, base flow, and sediment discharge measurements, they found that conservation tillage improved hydrologic responses, i.e., smaller amounts of storm-driven runoff and more base flow, reduction in sediment discharge annually and during peak storm events, and reduced sediment discharge between rough fallow and crop development.

Robertson and Roerish (1999) analyzed extensive stream flow and water quality data from eight small streams (14 to $110 \mathrm{~km}^{2}$ ) in southern Wisconsin, which were systematically subsampled to represent various water-quality sampling strategies. Water samples were collected approximately every two weeks from March through October and monthly in other months. They found that estimation of annual total phosphorous and suspended solids loads by regression was imprecise regardless of the sampling strategy used. Robertson and Roerish reported that the most effective sampling strategy depended on the length of the study. For one-year studies, fixed-point monthly sampling supplemented by storm chasing (i.e., collecting additional samples during storm events) was the most effective strategy. For studies of two or more years, fixed-period semimonthly sampling resulted in not only the least biased but also the most precise loads. Additional high-flow samples, typically collected to help define the relation between high stream flow and high loads, resulted in imprecise, overestimated loads if these samples were consistently collected early in high-flow events.

Shirmohammadi et al. (1997) monitored the 346-ha Warner watershed in Frederick County, Maryland, to assess the status, nature, and magnitude of nonpoint-source pollution in the Monocacy River Basin, a sub-basin of the Middle Potomac River contributing to Chesapeake Bay. The investigators measured flow, sediment, and nutrient constituents (ammonia-N, nitrate- $\mathrm{N}$, nitrite-N, TKN, orthophosphate, and total $\mathrm{P}$ ) at different stations throughout the watershed and presented some of the data measured during 1993-1997 and the results of their analyses. They observed that subsurface lateral flow plays a major role in nitrate-N loading to the stream in the Piedmont physiographic region, thus making nutrient management a priority in upland agricultural fields.

Mitchell et al. (2000) monitored the $489 \mathrm{~km}^{2}$ Little Vermilion River watershed in east central Illinois, discharging into Georgetown Lake. Monitoring stations were located along the main stem of the river and at eight tile drain outlets. They found nitrate- $\mathrm{N}$ concentrations in the river followed a pronounced seasonal cycle and no significant differences in nitrate-N concentration along the length of the river. Nitrate- $\mathrm{N}$ concentrations in tile drain effluent were higher from fields where greater amounts of $\mathrm{N}$ fertilizer were applied, particularly when the fertilizer was applied prior to planting.

Gentry et al. (1998) monitored a field-sized (40 ha) watershed in the Upper Embarras River Basin in central 
Illinois used to grow seed corn and soybeans to relate inorganic $\mathrm{N}$ pools with annual losses of nitrate- $\mathrm{N}$ in tile drains. Soil samples in the top $50 \mathrm{~cm}$ located near the tile systems were analyzed for microbial biomass carbon (C) and $\mathrm{N}$, inorganic $\mathrm{N}$, and $\mathrm{N}$ mineralization rates. Water flow and nitrate- $\mathrm{N}$ concentrations were continuously measured in the three tile drains. The investigators summarized three years of data and the results of data analyses. They found that tile $\mathrm{N}$ export from the watershed was greatest during high flow events when there were large pools of soil inorganic $\mathrm{N}$ in the form of nitrate- $\mathrm{N}$.

In a parallel effort to the Gentry et al. (1998) study, David et al. (1997) measured nitrate-N concentrations in the Upper Embarras River near the tile drain field and at a downstream USGS gauging station in Camargo, Illinois, with a drainage area of $482 \mathrm{~km}^{2}$. The investigators reported four years of nitrate- $\mathrm{N}$ concentrations at four tile drain outlets (partial data) and at the two Upper Embarras River locations (continuous data in weekly/biweekly intervals). After their analyses, the investigators found that high-flow events contributed most of the yearly nitrate-N loss from the tile-drained fields. In one tile drain, $21 \%$ of the annual load was exported in one day in the 1995 water year.

Arheimer and Liden (2000) analyzed nutrient species from 35 catchments ( 2 to $35 \mathrm{~km}^{2}$ ) in Sweden, monitored for an average of five years. They found strong correlation between inorganic $\mathrm{N}$ and land use, while concentrations of different phosphorous species were highly correlated to soil texture. They also found that phosphorous and inorganic $\mathrm{N}$ concentrations were elevated during flow increase at lowflow conditions, while they were diluted as the wetness in the catchment increased.

\section{Lake Decatur Watershed Study}

The Illinois State Water Survey, or ISWS (Demissie et al., 1996), completed a two-year monitoring and modeling study of the 2,396 $\mathrm{km}^{2}$ Upper Sangamon River basin draining into Lake Decatur in east central Illinois (fig. 1). Lake Decatur, the water supply reservoir for the city of Decatur, receives water from the entire Upper Sangamon River basin shown in figure 1 . The lake, having a maximum capacity of 34.5 million $\mathrm{m}^{3}$, has been experiencing water quality problems, with nitrate- $\mathrm{N}$ concentration occasionally exceeding the $10 \mathrm{mg} / \mathrm{L}$ drinking water standard of the U.S. and Illinois Environmental Protection Agencies (USEPA and IEPA). The goal of the study was to develop land-use management alternatives that would eventually bring the nitrate-N concentration in the lake below $10 \mathrm{mg} / \mathrm{L}$.

The ISWS established an extensive monitoring network throughout the watershed to monitor flow and concentrations of nitrate-N, ammonia-N, and TKN at eight monitoring stations: five tributary stations, and three main-stem stations along the Sangamon River (fig. 1). Monitoring of flows and nitrate- $\mathrm{N}$ concentrations continued beyond the initial twoyear period (Demissie and Keefer, 1998; Keefer and Demissie, 1999). As Demissie and Keefer (1998) reported, three-year data (1993-1996) showed that the first year, which was extremely wet with significant flow during the summer and fall, generated nitrate-N concentrations much higher than the following two years. The highest concentrations generally occurred in the period from March to May, and the lowest concentrations occurred in the period from August to October. The variability of nitrate-N concentration in the Sangamon River from upstream to downstream was not significant; however, the upstream station usually had slightly higher concentrations than the downstream stations. In general, two upstream tributaries (Big Ditch and Camp Creek) had higher nitrate-N concentrations, and two downstream tributaries (Friends Creek and Long Creek) had lower nitrate- $\mathrm{N}$ concentrations. However, these relative variations were not consistent.

As Borah et al. (2002a) reported, the Agricultural Non-Point Source (AGNPS) pollution model (Young et al., 1987) was used to evaluate the effects of alternative management practices on nitrate-N loading into Lake Decatur. The first two years of data were used to calibrate and validate the model. Model results showed that the effect of nutrient management on nitrate- $\mathrm{N}$ discharge into Lake Decatur was proportional to the area of application regardless of its location. Mitigation projects and conservation practices applied closer to the lake were more effective than those applied farther away from the lake. Any BMP applied over the entire watershed was more effective than when applied over only a portion of it. A combination of BMPs may provide a feasible and practical solution. The AGNPS model generates overall responses from a storm, such as runoff volume, peak flow, sediment yield, and average concentrations of $\mathrm{N}$ and $\mathrm{P}$. It does not generate runoff hydrographs and time-varying responses of sediment and water quality parameters.

The Lake Decatur watershed study described above involved mostly monitoring and investigating long-term (seasonal and yearly) patterns of nitrate- $\mathrm{N}$ concentrations and loads throughout the watershed. However, single-event storms, including intense storms, are responsible for transporting most of the sediment and chemicals from different parts of the watershed to the streams and ultimately to Lake Decatur and, therefore, deserve more attention. The study described in this article involves intensive monitoring of this watershed at three stations for various constituents during rainfall events at smaller time intervals.

\section{Methods and Materials \\ LAKe Decatur Watershed: The UpPer SANGAMon RIVER BASIN}

The Upper Sangamon River basin, draining the 2,396- $\mathrm{km}^{2}$ watershed into Lake Decatur in east central Illinois (fig. 1), is the focus of this study. The watershed lies in the Till Plains section of the Central Lowland physiographic province. Bed slope of the main stem Upper Sangamon River varies from 0.00017 to $0.00084 \mathrm{~m} / \mathrm{m}$, with an average of $0.00049 \mathrm{~m} / \mathrm{m}$. Slopes in the major tributaries vary mostly from 0.00053 to $0.00088 \mathrm{~m} / \mathrm{m}$, rarely up to $0.00538 \mathrm{~m} / \mathrm{m}$. The soils are mostly silt loams and silty clay loams, poorly drained, and are very fertile, with high organic content and high resistance to drought. The watershed has extensive tile drainage, a typical east central Illinois farming practice.

Agriculture is the dominant land use, with row crops (corn and soybeans rotation) covering $87 \%$ of the basin (Demissie et al., 1996). Fertilizer is applied for corn production, and anhydrous ammonia is the most common fertilizer. Generally, corn is planted in Champaign County between the third week in April until about mid-May (Roberts, 2002). McIsaac (2002) conducted a survey of $\mathrm{N}$ fertilizer applications in the 
Big Ditch watershed. He found consistencies in the 1995 and 2000 surveys. Based on these two surveys, he concluded that about $40 \%$ of the $\mathrm{N}$ fertilizer was applied in the fall, $10 \%$ was applied at side-dress times (approximately 15 May), and the remaining 50\% was applied sometime between February and early April. Based on county-level semi-annual sales data, McIsaac (2002) also found that for the 1998 crop year, $47 \%$ of the fertilizer was sold between July and December 1997, and the remaining 53\% was sold between January and June 1998. For the 1999 crop year, $71 \%$ was sold during July-December 1998, and the remaining $29 \%$ was sold during January-June 1999.

Herbicide applications occur at planting, and corn herbicides are sometimes applied as early pre-plant applications, usually 1 to 30 days prior to planting (Roberts, 2002). Post-emergence applications can occur anytime after the corn is planted but generally after 4 to 6 weeks.

\section{Monitoring Procedures}

The 1998 monitoring was conducted at the Big Ditch station, while the 1999 monitoring was conducted at Big Ditch, Fisher, and Mahomet (fig. 1). Storm events were targeted during the spring and early summer months, ideally before and after the applications of fertilizers and pesticides. Monitoring involved measurements of water discharges and collection of water samples for analyses of nitrate-N, orthophosphate, total suspended solids (TSS) or suspended sediment, and three pesticides (atrazine, metolachlor, and alachlor).

Continuous stage records and stage-discharge rating curves were used to calculate water discharge. Stage-discharge rating curves were developed during the earlier study (Demissie et al., 1996) from many physical measurements of water velocities using a standard rotating bucket current meter and water cross-sectional areas at each monitoring station during many different flow conditions and water levels.

Samples for the analyses of nitrate-N, orthophosphate, and TSS were collected using a time-integrated automatic water sampler (ISCO, 1975) at specified time intervals. Water is pumped through a plastic tube whose inlet is submerged in the water. The other end of the tube is connected to the sampler. Sampling intervals were generally $3 \mathrm{~h}$ during the rising, peak, and immediately after the peak of a storm hydrograph, and up to $6 \mathrm{~h}$ during recession. During each sampling interval, two instantaneous samples were collected in two $500 \mathrm{~mL}$ polyethylene bottles. Each tray, holding a maximum of 28 samples collected at 14 different time intervals, was retrieved within three days of setup for the shorter time interval sampling and within seven days for longer interval sampling. Samples from the trays were labeled with time and date of collection for each group of parameters. One sample from each time interval was sent to the chemistry laboratory for analyses of nitrate- $\mathrm{N}$ and orthophosphate, and the other sample (in a pre-weighed bottle) was sent to the sediment laboratory for analysis of TSS. There was the possibility of exceeding the holding times recommended by the USEPA $(1983,1993)$ for the samples to be analyzed for nitrate-N and orthophosphate. Therefore, grab samples were collected at the time of setup of the automatic sampler. Immediately after the grab sample was collected, the sampler was triggered to collect its first sample. Experience with comparisons of analytical results of the grab samples and the sampler-collected samples for both parameters (nitrate-N and orthophosphate) showed that little to no degradation occurs in samples analyzed up to 10 days beyond the recommended holding times.

More grab samples were collected on visits to the stations during storm events for additional data points, and to compare TSS and chemical concentrations with the concentrations from the automatic samplers for quality control and quality assurance purposes. Analyses of the grab samples were critical because the automatic sampler usually collects samples from a point close to the water surface. Although the samples can be pumped from a certain depth using weights, with high velocities during intense storms, the inlet usually floats close to the surface. All grab samples were collected in 1-L glass jars, each of which was held inside an aluminum frame basket that was lowered on a rope into the stream at the thalweg (deepest thread of water), usually the midpoint of the stream where velocity is expected to be the highest. The glass jar was first rinsed with deionized water and then rinsed with resident (stream) water before the samples were taken and transferred to the appropriate storage container. Table 1 lists the container types, sample sizes, and storage practices used for each type of analysis. The sample number, date, and time of collection were recorded on the storage bottles for each parameter, and the bottles were then placed in a cooler kept at less than $4^{\circ} \mathrm{C}\left(39^{\circ} \mathrm{F}\right)$ and transported to the laboratory for analyses.

Due to their higher degradable properties and possibilities of cross contamination, samples from automatic samplers were not used for pesticide analyses. Additional grab samples were collected for pesticide analyses at the same time as the other grab samples.

To verify the accuracy of suspended sediment concentrations measured by grab and time-integrated automated samples collected at single points, a USGS DH-59 sampler (Guy and Norman, 1970) was used to collect depth-widthintegrated samples from the stream cross-section at the monitoring station during field visits. The stream cross-section was divided into several intervals. The sampler with an empty sample bottle was lowered to near the bottom of the stream and raised back to the surface in each cross-sectional interval at a constant speed, collecting a sediment-laden water sample. The sample bottle inside the DH-59 sampler gradually filled as it was being lowered and raised. If the sample bottle was filled past a specified level, the procedure was repeated with adjusted lowering and raising speeds and/or with a different nozzle size. The concentrations of all the samples from the cross-sectional intervals, measured using the analytical procedure listed in table 2, were weighted to compute the average concentration based on the cross-sectional areas of the intervals.

Table 1. Grab sample collection and handling.

\begin{tabular}{llcc}
\hline Parameter & Container & $\begin{array}{c}\text { Sample } \\
\text { Size }\end{array}$ & $\begin{array}{c}\text { Holding } \\
\text { Time }\end{array}$ \\
\hline Nitrate-nitrogen & Polyethylene bottle & $60 \mathrm{~mL}$ & 2 days, $4^{\circ} \mathrm{C}$ \\
Orthophosphate & Polyethylene bottle & $60 \mathrm{~mL}$ & 2 days, $4^{\circ} \mathrm{C}$ \\
Total suspended solids & Glass bottle & $500 \mathrm{~mL}$ & 7 days \\
Pesticides (atrazine, & Amber glass bottle & $1000 \mathrm{~mL}$ & 7 days until \\
alachlor, and metolach- & with Teflon-lined & & $\begin{array}{c}\text { extraction, } 4^{\circ} \mathrm{C} \text {; } \\
\text { lor) }\end{array}$ \\
& cap (solvent- & & 40 days after \\
& washed) & & extraction \\
\hline
\end{tabular}


Table 2. Methodologies for chemical and sediment analyses of water samples.

\begin{tabular}{lcc}
\hline Analyte & $\begin{array}{c}\text { IEPA } \\
\text { Method } \\
\text { Number }\end{array}$ & $\begin{array}{c}\text { Methodology } \\
\text { (and Source) }\end{array}$ \\
\hline $\begin{array}{l}\text { Nitrate-nitrogen } \\
\text { Orthophosphate }\end{array}$ & 300.0 & $\begin{array}{c}\text { Ion chromatography } \\
\text { (USEPA, 1993) } \\
\text { Pesticides (atrazine, alachlor, } \\
\text { and metolachlor) }\end{array}$ \\
$\begin{array}{l}\text { Total suspended solids } \\
\text { (USEPA, 1983) }\end{array}$ & 507 & $\begin{array}{c}\text { Gas chromatography } \\
\text { (USEPA, 1991) }\end{array}$ \\
\hline
\end{tabular}

The analyses for the parameters of nitrate-N, orthophosphate (phosphate-P), and pesticides were performed at the Analytical Chemistry Laboratory of the ISWS. The sediment laboratory of the ISWS performed the analysis for suspended sediment. Table 2 lists the analytes, IEPA method number, and specifies the procedures used by the laboratories.

\section{ReSUlTS AND DisCUSSION}

\section{Consistency of SAMPLing Methods}

Most of the time-integrated samples for analyses of TSS, nitrate- $\mathrm{N}$, and phosphate- $\mathrm{P}$ were taken using an ISCO automatic sampler, which pumps water samples from a point close to the water surface. This brings the question of representative samples and accuracy of the concentrations of the above constituents measured from these samples. In order to answer these quality control and quality assurance questions, concentrations of different constituents measured from different sampling methods during the 1998 monitoring period were graphically compared. In these comparisons, the coefficient of determination $\left(\mathrm{R}^{2}\right)$ was computed, and linear regression equations were derived. These analyses and graphs were reported in Borah et al. (1999), and a brief overview is presented here.

Concentrations of nitrate- $\mathrm{N}$ from automated collected samples and grab samples were almost a perfect match with $\mathrm{R}^{2}=0.98$, and slope of the linear fit $=0.99$. There appeared to be an outlier in the phosphate-P comparison, with one of the ten data points deviating from the general trend. Even with that outlier, the $\mathrm{R}^{2}$ was 0.93 , and slope of the regression was 1.04, indicating a good match of concentrations between the automated collected and grab samples. From these results, it was concluded that the automated collected samples were consistent with the grab samples and showed no or negligible sample degradation for nitrate- $\mathrm{N}$ and phosphate-P constituents.

Depth-width-integrated sampling with the DH-59 sampler gives a more representative and accurate measurement of suspended sediment concentration than the other methods due to its intensive sampling procedure. Results from the grab and DH-59 samples were almost a perfect match, with $\mathrm{R}^{2}=0.99$ and slope of linear regression $=0.95$. However, the $\mathrm{R}^{2}$ and slope reduced to 0.97 and 0.83 in the case of the automated collected versus DH-59 samples due to the single highest concentration point, with the automatic sampler measuring almost $130 \mathrm{mg} / \mathrm{L}$ more suspended sediment. Differences are expected during falling stages and low flows, when pronounced concentration gradient could exist, with higher concentrations near the bed and lower concentrations near the surface, depending on the sediment size distribution.
Such phenomena are frequently observed in Indian streams (Kumar, 2002). Although the comparison of grab and automated collected samples was very good, with $\mathrm{R}^{2}=0.99$ and regression slope $=1.10$, the two highest suspended sediment concentrations were samples collected with the automatic sampler.

From these results, it can be concluded that the suspended sediment was well mixed and distributed in the Big Ditch stream cross-section during the intense storm events monitored. Therefore, the grab and the automatic samplers were producing concentrations similar to those of the DH-59 sampler. More data points on the stream hydrograph during rising, peak, and falling limbs, as well as base flows, are required to reach definitive conclusions regarding consistencies or differences of methods.

\section{Data Collected at Big Ditch Station During 1998 SPRING STORMS}

During 1998, intensive monitoring of the Big Ditch streamgage station (fig. 1), draining a $98 \mathrm{~km}^{2}$ subwatershed of the Lake Decatur watershed, was carried out. As shown in figure 1, the monitoring station (streamgage) on Big Ditch was located approximately $8 \mathrm{~km}$ upstream of its confluence with the Sangamon River to avoid backwater effects from the main stem. Continuous flow and intermittent concentrations of suspended sediment, nitrate-N, phosphate-P, atrazine, metolachlor, and alachlor were measured during the spring and early summer storms of 1998. A new, tipping-bucket raingage with electronic data logger was installed in April 1998 near the Big Ditch monitoring station (raingage 6), where continuous measurements of rainfall were recorded.

Figure 2 shows cumulative rainfall and intermittent suspended sediment concentrations, both with hourly water discharges (hydrograph) at the Big Ditch station throughout the 1998 monitoring period. Rainfall measurements were recorded starting from the end of April. As shown by the hydrograph and rainfall records (fig. 2a), major storms occurred during March, May, and June. Sample collection during the latter part of March (fig. 2b) was affected by associated snow and freezing rain. Extensive samples were collected during and after intense rainfall events in May and June. A few grab samples were collected during the dry and remaining portions of the monitoring period. As shown in figure $2 \mathrm{~b}$, sediment concentrations closely followed the water discharge hydrograph. Analysis of the sediment concentrations with water discharge, shown in figure 3, reveals that sediment concentration varied from month to month during the growing season.

Relationships were developed for all monitored constituent concentrations (suspended sediment, nitrate-N, phosphate-P, atrazine, and metolachlor) with water discharge. Both linear and nonlinear regression equations were used to relate constituent concentrations to water discharge on a monthly and seasonal basis. Data for each month (March, May, and June) were grouped, and an individual regression equation for each month was developed in addition to the combined equation for all the data. Although the sediment equations in figure 3 , which are linear, have low $\mathrm{R}^{2}$ values (0.54 to 0.71$)$, they show clear patterns for different months. Individual months have higher $\mathrm{R}^{2}$ values $(0.68$ for March, 0.71 for May, and 0.58 for June) than the combined period (0.54). This shows the temporal variation during the growing season due to climate, ground cover, and management 

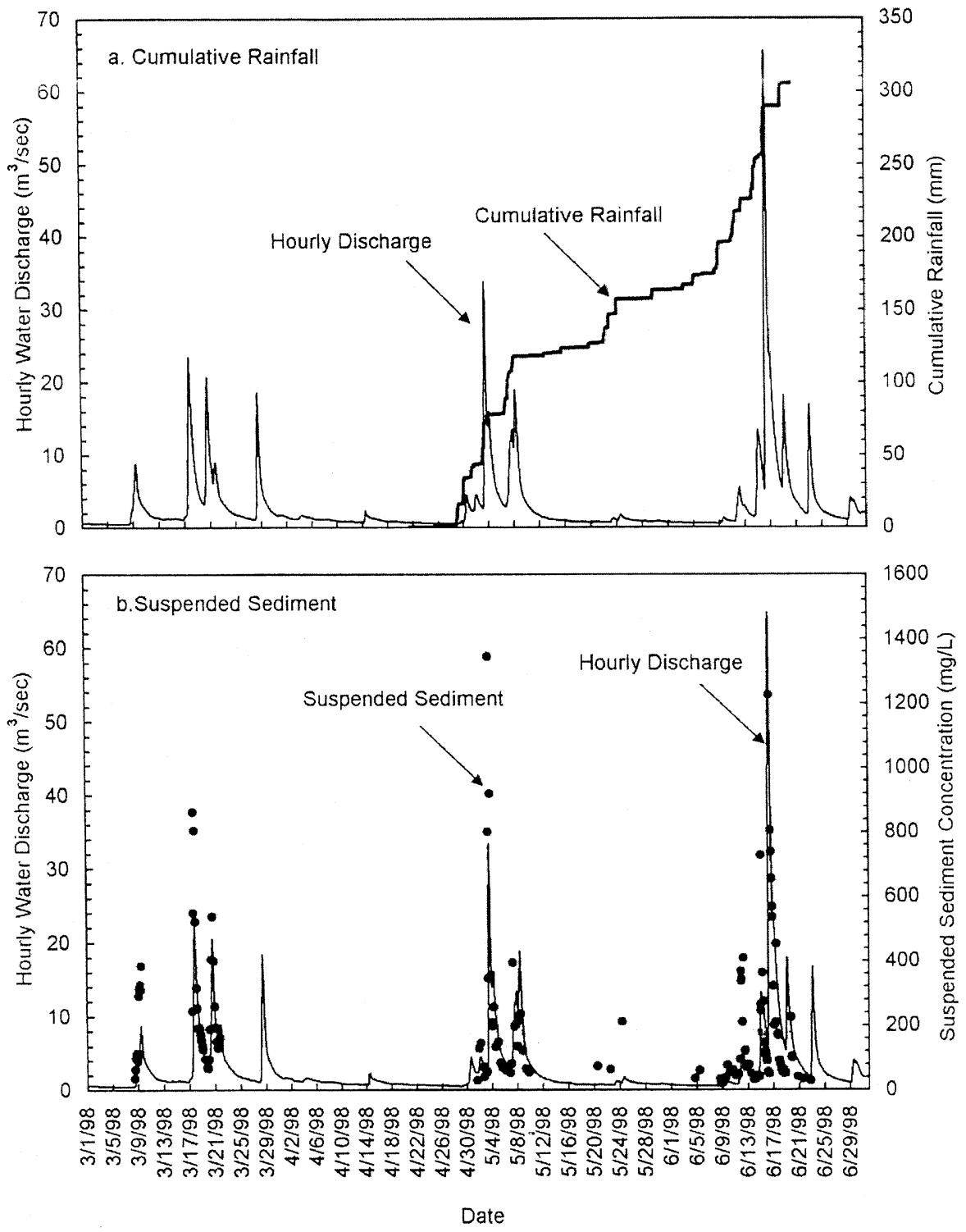

Figure 2. Observed data at Big Ditch monitored during 1998: (a) hourly discharge and cumulative rainfall, and (b) hydrograph and concentrations of suspended sediment.

practices. Sediment concentrations with respect to water discharge were relatively high during March (fig. 3), which may be due to more erodible soils immediately following freezing conditions, and also due to low ground cover on much of the watershed. The sediment concentrations with respect to the water discharges gradually reduced in May and significantly reduced in June, reflecting establishment of crops in the fields. The highest flow and sediment concentration during May were approximately $34 \mathrm{~m}^{3} / \mathrm{s}$ and $1,320 \mathrm{mg} / \mathrm{L}$, respectively. In June, the highest flow and sediment concentration were approximately $65 \mathrm{~m}^{3} / \mathrm{s}$ and $1,200 \mathrm{mg} / \mathrm{L}$, respectively. Such high concentrations of sediment may be due to intense and highly erosive rainfall and runoff.

Figure 4 shows concentrations of nitrate- $\mathrm{N}\left(\mathrm{NO}_{3}-\mathrm{N}\right)$ and phosphate-P $\left(\mathrm{PO}_{4}-\mathrm{P}\right)$ along with the hydrographs at the Big Ditch station throughout the 1998 monitoring period. Figure 5 shows relationships of these constituent concentrations with water discharge. As shown in figures $4 \mathrm{a}$ and $5 \mathrm{a}$, nitrate- $\mathrm{N}$ concentrations tended to be lower for high discharges, decreasing drastically during rising and peak flows and increasing with the recession and base flow portions of the hydrographs. Such variations may be due to the pathways of flow. Water flowing through subsurface soil and tile drain contains more nitrate- $\mathrm{N}$ than water flowing over the ground surface (Mitchell et al, 2000; David et al., 1997). Therefore, high flows from intense storms, primarily surface runoff, contain less nitrate- $\mathrm{N}$ than water in the recession and base flows (fig. 4a), where nitrate- $\mathrm{N}$ is contributed mainly by tile drain and subsurface flows through the soil matrix. In addition, higher concentrations of nitrate- $\mathrm{N}$ may be noticed in the water before and after peak flows, which may be due to a naturally controlled release rate of nitrate-N from the soil up to a maximum rate or threshold. The threshold may be reached before the peak flow, beyond which dilution occurs until the flow becomes lower than the threshold.

An exponential decay function fitted most of the relationships for nitrate- $\mathrm{N}$ concentration with water discharge. As shown in figure $5 \mathrm{a}$, data from different months clearly 


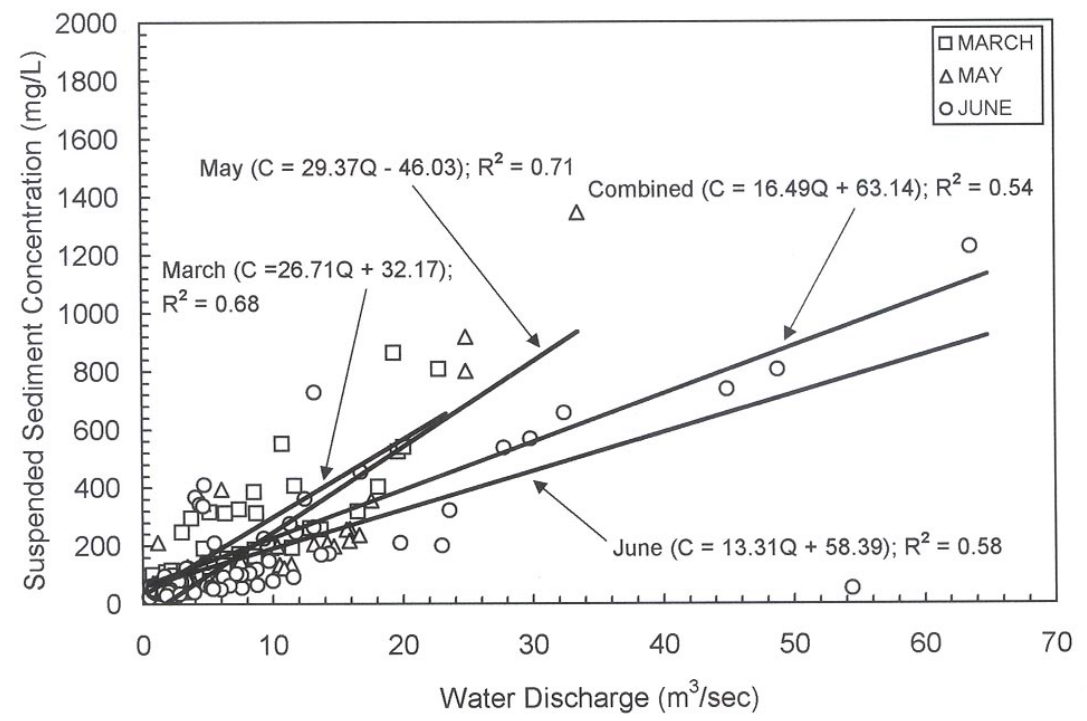

Figure 3. Suspended sediment concentration versus water discharge at the Big Ditch station from observations made during 1998 and shown in figure 2b.
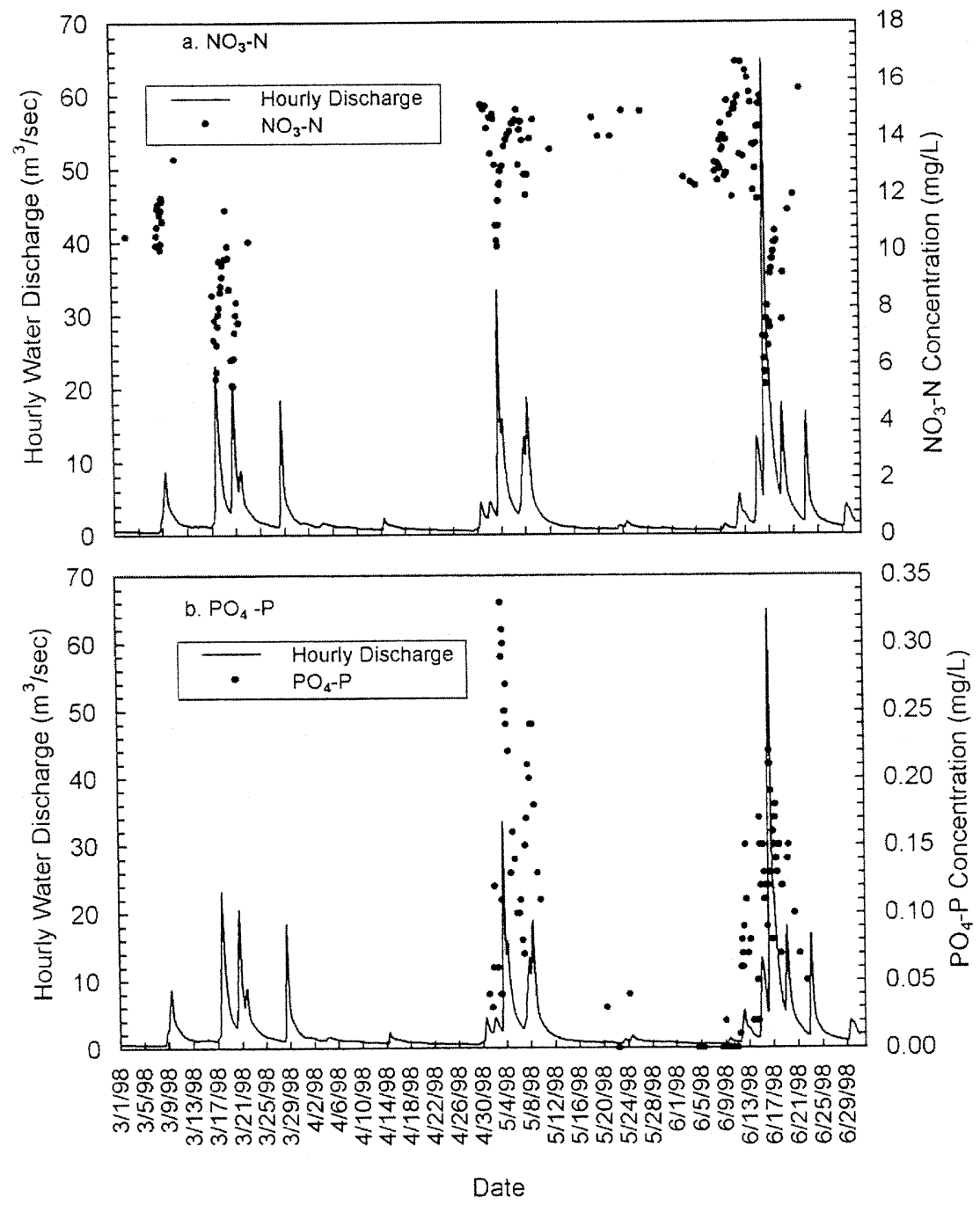

Figure 4. Observed data at Big Ditch monitored during 1998: (a) hydrograph and concentrations of nitrate-N, and (b) hydrograph and concentrations of phosphate-P. 

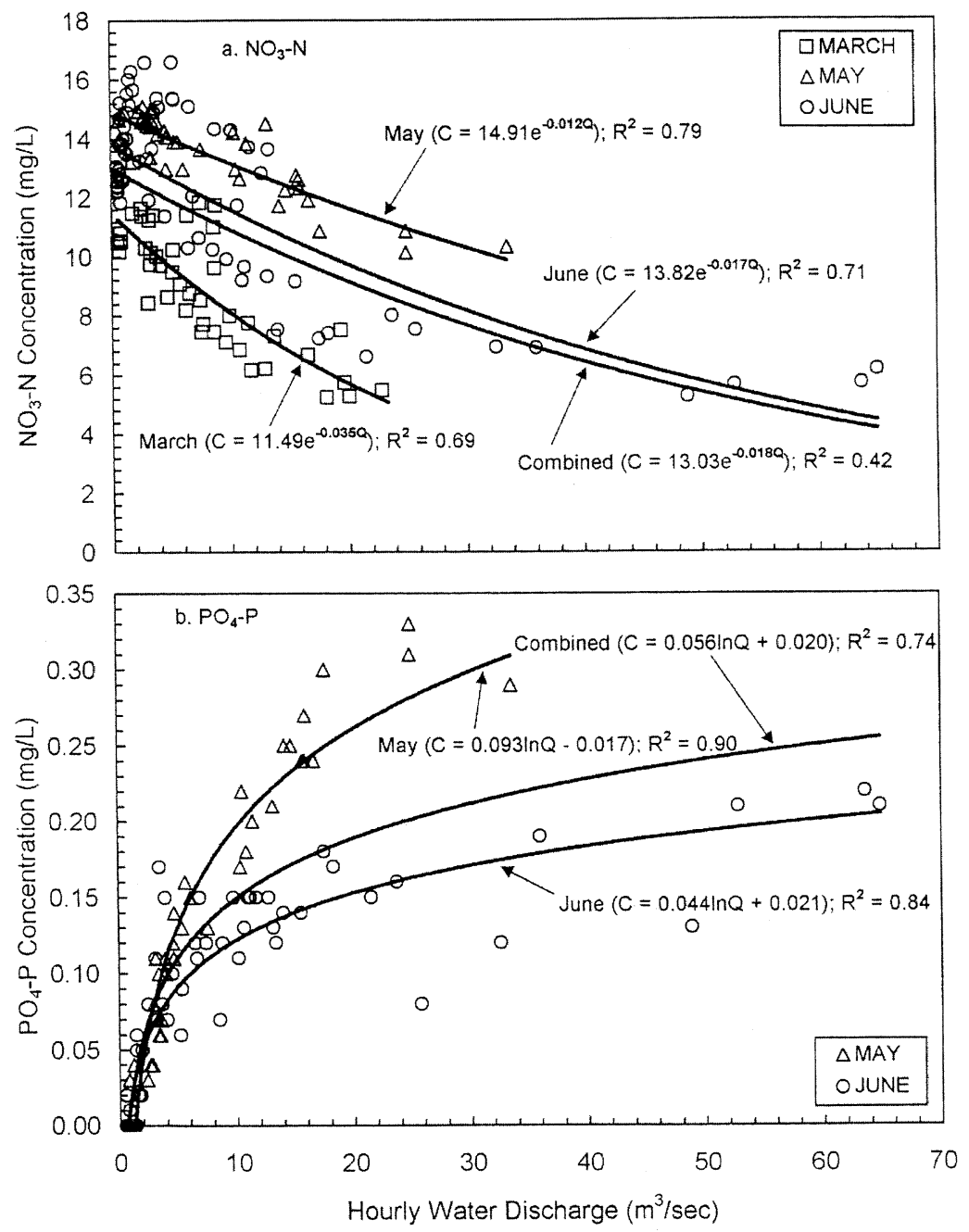

Figure 5. Nutrient concentrations versus water discharge at the Big Ditch station from observations made during 1998: (a) nitrate-N, and (b) phosphate-P.

showed different relationships. Although $\mathrm{R}^{2}$ values for the individual months were not very high (0.69 to 0.79$)$, they were higher than the combined value $(0.42)$.

Nitrate-N load for the monitoring period was computed by multiplying the hourly water discharges with nitrate-N concentrations calculated from the regression functions shown in figure $5 \mathrm{a}$ and then summing all the values for the period. The total nitrate-N load for the 1998 monitoring period was computed as 305 metric tons (t). Contributions from March, May, and June were 75, 109, and $121 \mathrm{t}$, respectively. Based on weekly samples over a five-year (May 1993 to April 1998) period, Keefer and Demissie (1999) estimated an average annual yield of $31 \mathrm{~kg} / \mathrm{ha}$, or $308 \mathrm{t}$ load, at the Big Ditch station. The annual loads varied from 163 to $544 \mathrm{t}$ per year. Therefore, the total nitrate- $\mathrm{N}$ load during the 1998 spring storms was similar to the five-year average annual load. This indicates that the single storm events during the spring of 1998 carried most of the yearly load and, therefore, these individual storm events deserve close attention.

As shown in figures $4 \mathrm{~b}$ and $5 \mathrm{~b}$, phosphate-P concentration followed the runoff hydrograph similarly to sediment, which may be due to its adhesive properties with sediment. Unlike the sediment, the phosphate-P regression functions are logarithmic or power functions approaching a limiting value.
Curves for individual months had higher $\mathrm{R}^{2}$ values $(0.90$ for May and 0.84 for June) than the combined curve $\left(\mathrm{R}^{2}=0.74\right)$, indicating monthly variation.

Figure 6 shows the concentrations of atrazine and metolachlor along with the hydrograph at the Big Ditch station during the 1998 monitoring period. Since these two herbicides were monitored by grab samples, data points for these constituents are fewer than those for sediment and nutrients. Similar to sediment and phosphate-P, concentrations of these herbicides also followed the hydrograph. The highest concentrations ( 33 and $28 \mu \mathrm{g} / \mathrm{L}$ ) were observed for atrazine and metolachlor, respectively, in early May 1998 (fig. 6), which is in the middle of corn planting and herbicide application in the northern half of Illinois (Roberts, 2002). After a month-long period of dry weather, rain may have fallen immediately after applications of the herbicides to generate such high concentrations. Figure 7 shows the relationships of atrazine and metolachlor concentrations with water discharge, both combined and monthly. For both constituents, goodness-of-fit for individual month relationships was stronger than for the combined months, except for atrazine in June due to higher concentrations for the low flows that occurred early in the month. In general, logarithmic or power functions approaching limiting values generated higher $\mathrm{R}^{2}$ values than were generated by linear 

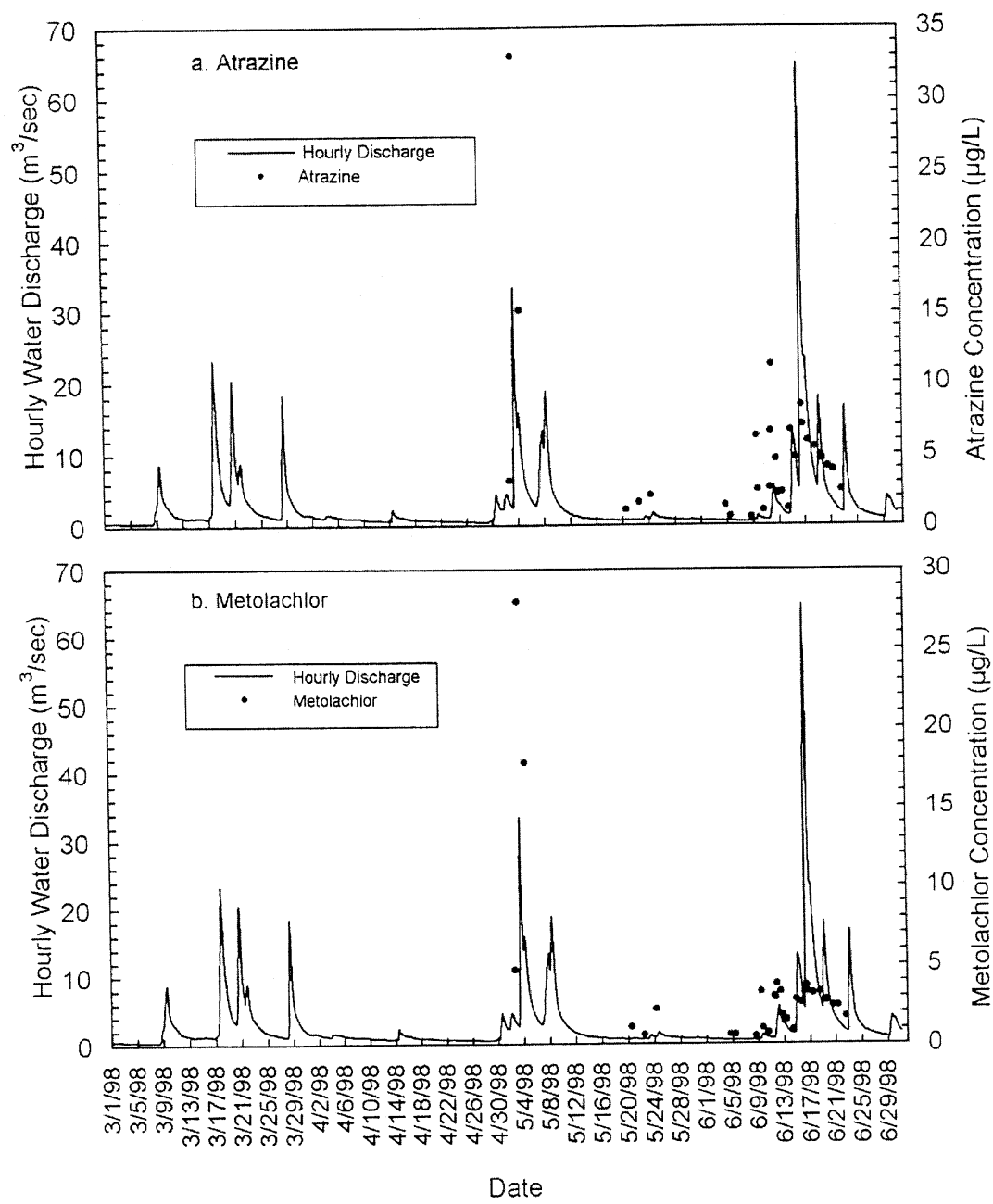

Figure 6. Observed data at Big Ditch monitored during 1998: (a) hydrograph and concentrations of atrazine, and (b) hydrograph and concentrations of metolachlor.

regression. Only the May data with linear regression showed higher $\mathrm{R}^{2}$ (1.00 for atrazine and 0.96 for metolachlor). Analyses for alachlor did not detect this herbicide in water samples. The relationships shown in figures 3,5 , and 7 may be useful in predicting constituent concentrations in Big Ditch and similar watersheds under similar geographic, geological, climatic, and land management conditions and under similar rainfall intensity, pattern, and distribution.

\section{Data Collected at Stations above Mahomet during 1999 SPRING STORMS}

During 1999, two additional stations in the Upper Lake Decatur watershed were monitored. These stations were Fisher and Mahomet (fig. 1), both located in the main stem of the Sangamon River and draining 622 and $932 \mathrm{~km}^{2}$ of the Upper Sangamon River (Lake Decatur) watershed, respectively. Monitoring was continued at the Big Ditch station. Flow and concentrations of suspended sediment, nitrate-N, and phosphate-P were monitored at all three stations during the spring and early summer storm events of 1999. Only one herbicide was monitored due to budget constraints. Atrazine was chosen because it showed a similar pattern but higher concentration with respect to metolachlor in Big Ditch during 1998 (fig. 6). Similar to the Big Ditch station, Mahomet was equipped with an automatic sampler; however, Fisher did not have one due to installation difficulties.

Five additional tipping-bucket raingages (raingages 1 to 5) were installed in the Upper Lake Decatur watershed to measure the spatial distribution of rainfall (fig. 1). Data collection from the raingage installed in April 1998 near the Big Ditch monitoring station (raingage 6) was also continued. Figure 8 shows the cumulative rainfall observed at these stations along with hourly water discharges at Big Ditch, Fisher, and Mahomet during the 1999 monitoring period. The raingages were installed at different times; therefore, the records for the different gages began at different times, especially raingage 4, which was installed on 22 April 1999 (fig. 8a). As may be seen from these rainfall records, the six stations recorded noticeably variable rainfall amounts, especially the western stations $(1,2$, and 3$)$ versus the eastern stations $(4,5$, and 6$)$. The only intense storm recorded in all the gages was on 15-16 April 1999 (approximately $76 \mathrm{~mm}$ ) (fig. 8a). Varying rainfall depths were observed at different gages on 13 May, 2 June, 14 June, and 23 June. High flows at each of the three monitoring stations occurred during the intense storm of 15-16 April (fig. 8b). The peak and flow duration at the stations for this uniformly distributed storm increased as the drainage basins increased from $98 \mathrm{~km}^{2}$ for Big Ditch to $622 \mathrm{~km}^{2}$ and $932 \mathrm{~km}^{2}$ for Fisher and Mahomet, respectively. 

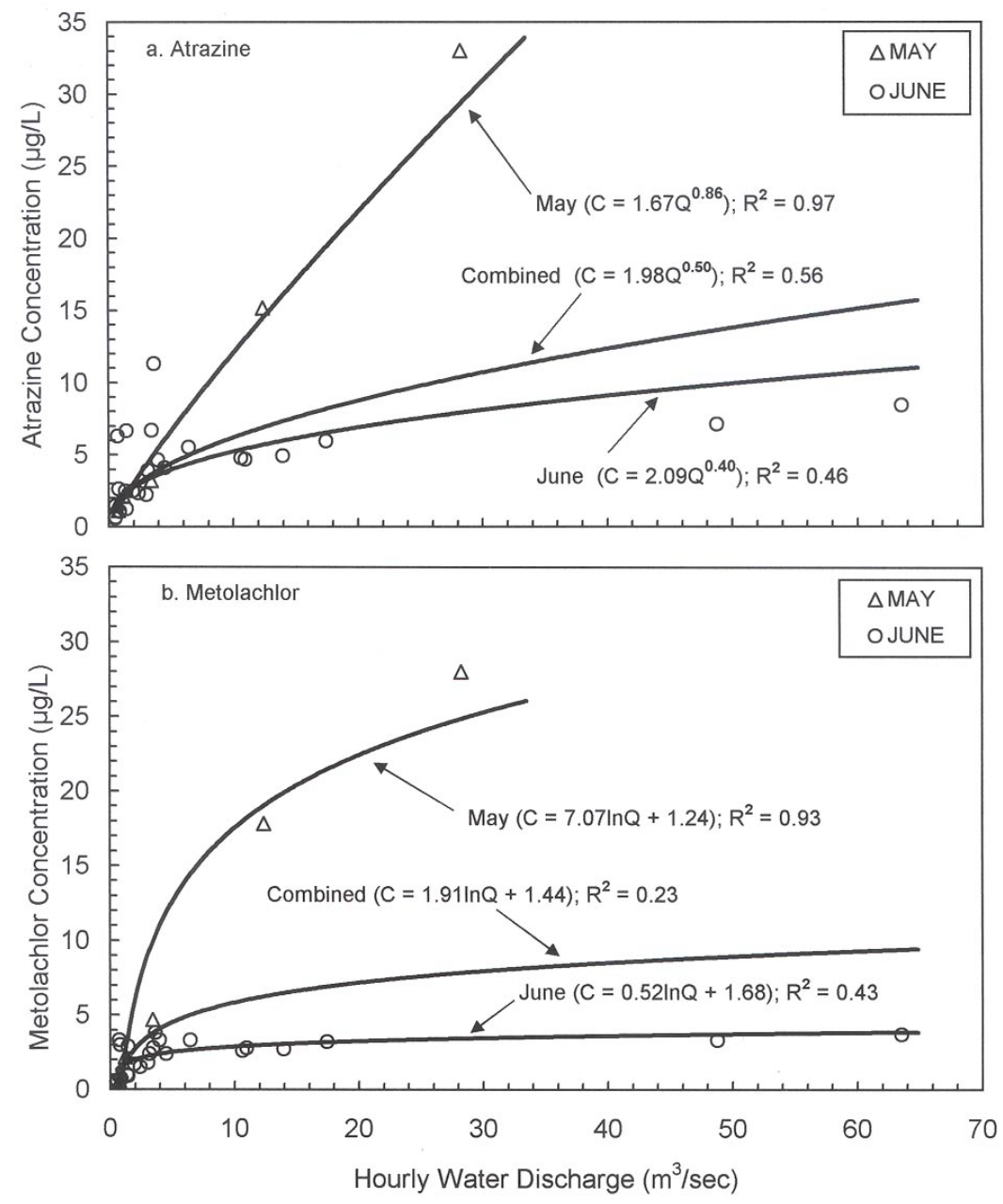

Figure 7. Herbicide concentrations versus water discharge at the Big Ditch station from observations made during 1998: (a) atrazine, and (b) metolachlor.

The varying rainfall on 13 May, 2 June, 14 June, and 23 June, shown in figure $8 \mathrm{a}$, resulted in different responses at the three stream monitoring stations (fig. 8b). Raingages 5 and 6 in the Big Ditch subwatershed (fig. 1) recorded very little rain on these dates, and the hydrograph for the Big Ditch station showed very little flow (fig. 8b). Raingages 3 and 4 (fig. 1), located at the upper part of the watershed, recorded heavier rain on 2 June (fig. 8a). Flow increases during and after this storm were seen only in the main stem of the Sangamon River, producing peak flows close to 28 and $25 \mathrm{~m}^{3} / \mathrm{s}$ at downstream stations Fisher and Mahomet, respectively, (fig. 8b). The Mahomet hydrograph clearly shows the attenuation of $3 \mathrm{~m}^{3} / \mathrm{s}$ and time lag (approximately 2 days) of the flood peak from Fisher, the station located $26 \mathrm{~km}$ upstream of Mahomet. Similar phenomena occurred after the 14 and 23 June rainfalls (fig. 8b).

Figure 9 shows the concentrations of suspended sediment and nitrate-N, both with continuous measurements of water discharges (hydrograph) at the Big Ditch station throughout the 1999 monitoring period. Intensive measurements of the constituents were done during the storms of April and June, the remainder periodically for nitrate-N (fig. 9b). As expected, suspended sediment followed water discharge very closely (fig. 9a). The data fitted a similar regression function as shown in figure 3 , with a combined $\mathrm{R}^{2}$ of 0.70 . Regression of individual months (April and June) had similar $\mathrm{R}^{2}$ values (0.66 and 0.82 , respectively).

As shown in figure $9 \mathrm{~b}$, the inverse relationship of nitrate-N concentration with peak flow was not as noticeable as in the spring 1998 storms (fig. 4a), which may be due to lower peak flows in 1999. Nitrate-N concentrations were above $10 \mathrm{mg} / \mathrm{L}$ and went as high as $18.8 \mathrm{mg} / \mathrm{L}$ during the rising flows of the April and June storms (fig. 9b). Unlike the inverse (exponential decay) relationships from 1998 data (fig. 5a), the 1999 nitrate-N concentrations fitted nearly flat logarithmic functions (positive regression) with water discharge, resulting in $\mathrm{R}^{2}$ values of 0.83 for April, 0.92 for May, 0.34 for June, and 0.59 for combined. Total nitrate-N load for this monitoring period, as calculated by summing the product of hourly discharges and concentrations obtained from the regression functions, was $126 \mathrm{t}$. This was $40 \%$ of the previously observed average annual yield of $308 \mathrm{t}$. Contributions from April, May, and June were 71, 25, and $30 \mathrm{t}$, respectively.

A unique pattern may be observed with the nitrate- $\mathrm{N}$ concentrations in figure 9b. The major storm in April (peak $20 \mathrm{~m}^{3} / \mathrm{s}$ ) raised nitrate- $\mathrm{N}$ concentrations up to $18 \mathrm{mg} / \mathrm{L}$. During the hydrograph recession and base flow periods, a recession of nitrate- $\mathrm{N}$ concentration occurred, followed with further dropping of its concentration to $13 \mathrm{mg} / \mathrm{L}$ in mid-May, 

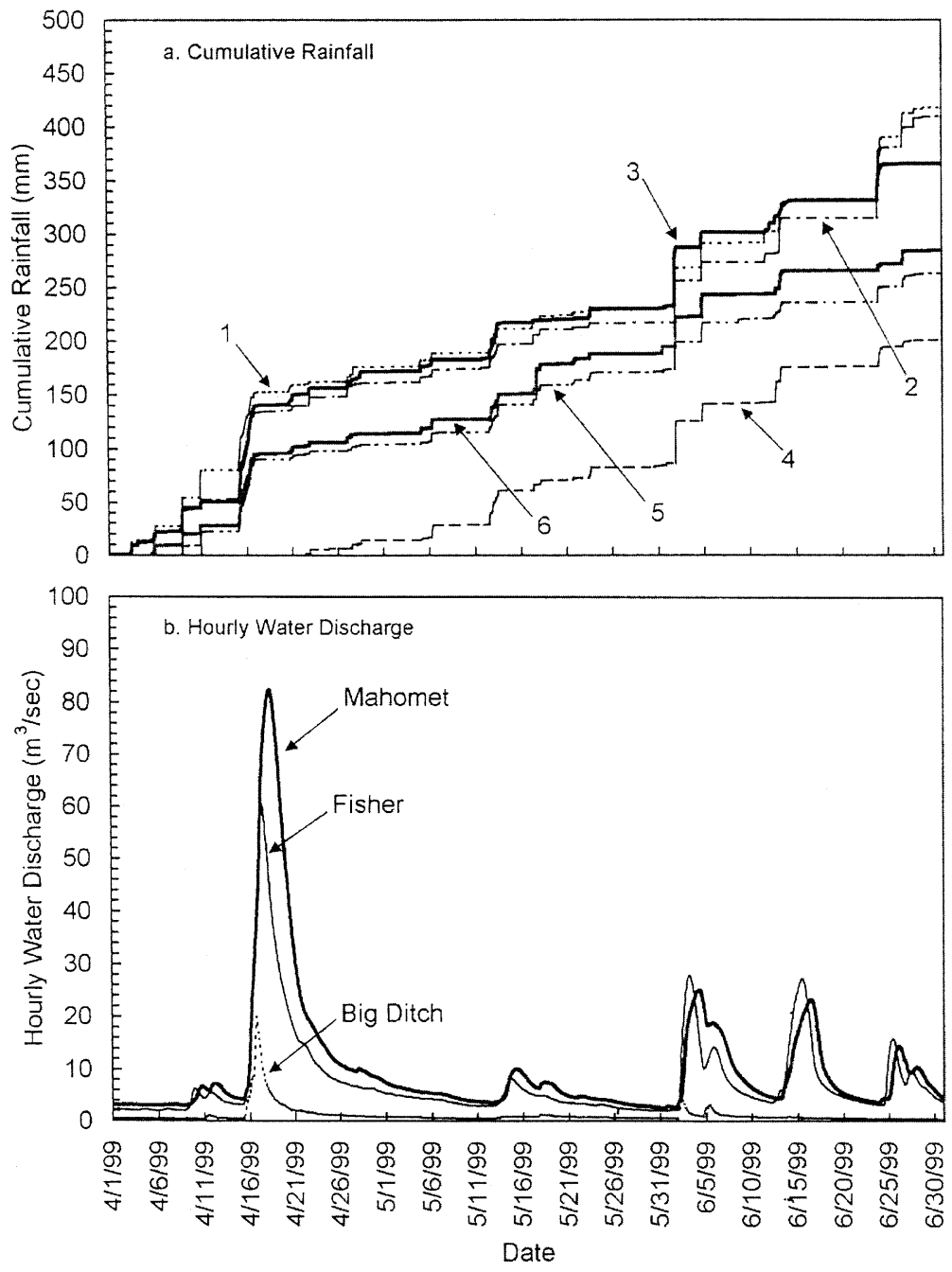

Figure 8. Rainfall and water discharges monitored during 1999 in the Upper Lake Decatur watershed: (a) cumulative rainfall at six raingages, and (b) hourly water discharges at monitoring stations.

until a small storm (peak runoff $1 \mathrm{~m}^{3} / \mathrm{s}$ ) occurred and the concentration increased to $15 \mathrm{mg} / \mathrm{L}$. The declining pattern continued during the remaining part of May and early June. A larger storm (peak runoff $4 \mathrm{~m}^{3} / \mathrm{s}$ ) than the May storm occurred in early June, which raised the concentration to $18.8 \mathrm{mg} / \mathrm{L}$. Such a pattern may be due to the timing of $\mathrm{N}$ application to the soil and/or the accumulation of nitrate in the soils during long dry periods, which is then flushed out with the occurrence of a storm. A similar pattern can also be seen in the 1998 observations (fig. 4a) before each of the major peaks, when the smaller peaks elevated nitrate-N concentrations followed by dilution with the higher peaks. Arheimer and Liden (2000) made similar observations in Swedish watersheds, where nitrate-N concentrations were elevated during flow increase at low-flow conditions and then diluted as the wetness in the catchment increased. Another reason for such a pattern may be that major storms enrich the pore waters with high nitrate- $\mathrm{N}$ concentrations through desorption, mineralization, and/or nitrification processes, enabling $\mathrm{N}$ to be mobilized through subsurface and tile flow. Smaller storms that do not have enough water for dilution carry those nitrate- $\mathrm{N}$ rich pore waters to the streams and elevate their concentrations.
Figure 10 shows concentrations of phosphate-P and atrazine along with the hydrographs at the Big Ditch station. As shown in the graphs, both phosphate-P and atrazine followed the hydrograph similarly to sediment. Phosphate-P showed a good relationship with water discharge (monthly $\mathrm{R}^{2}$ values of 0.57 to 0.94 , and 0.95 when combined). Atrazine concentrations were observed at $9 \mu \mathrm{g} / \mathrm{L}$ during the April high flows and as high as $18 \mu \mathrm{g} / \mathrm{L}$ during the June storms (fig. 10b). The high concentration in early June may have been due to the timing of herbicide applications. Herbicide applications occur mostly at planting, which is between the third week in April until mid-May in Champaign County, Illinois (Roberts, 2002). The atrazine concentration fitted similar power function relationships with water discharge as shown in figure $7 \mathrm{a}$, but with poor goodness-of-fit $\left(\mathrm{R}^{2}\right.$ values $=0.47$ for April, 0.80 for June, and 0.49 combined).

Figure 11 shows the concentrations of sediment and nitrate-N observed at the Mahomet station, draining a $932 \mathrm{~km}^{2}$ watershed. During the April storm, the peak sediment concentration preceded the hydrograph peak by nearly 2 days and occurred during the early part of the rising hydrograph. This is a different pattern from the Big Ditch subwatershed (fig. 9a), which may be due to the different sizes of the subwatersheds. Sediment concentration did not 

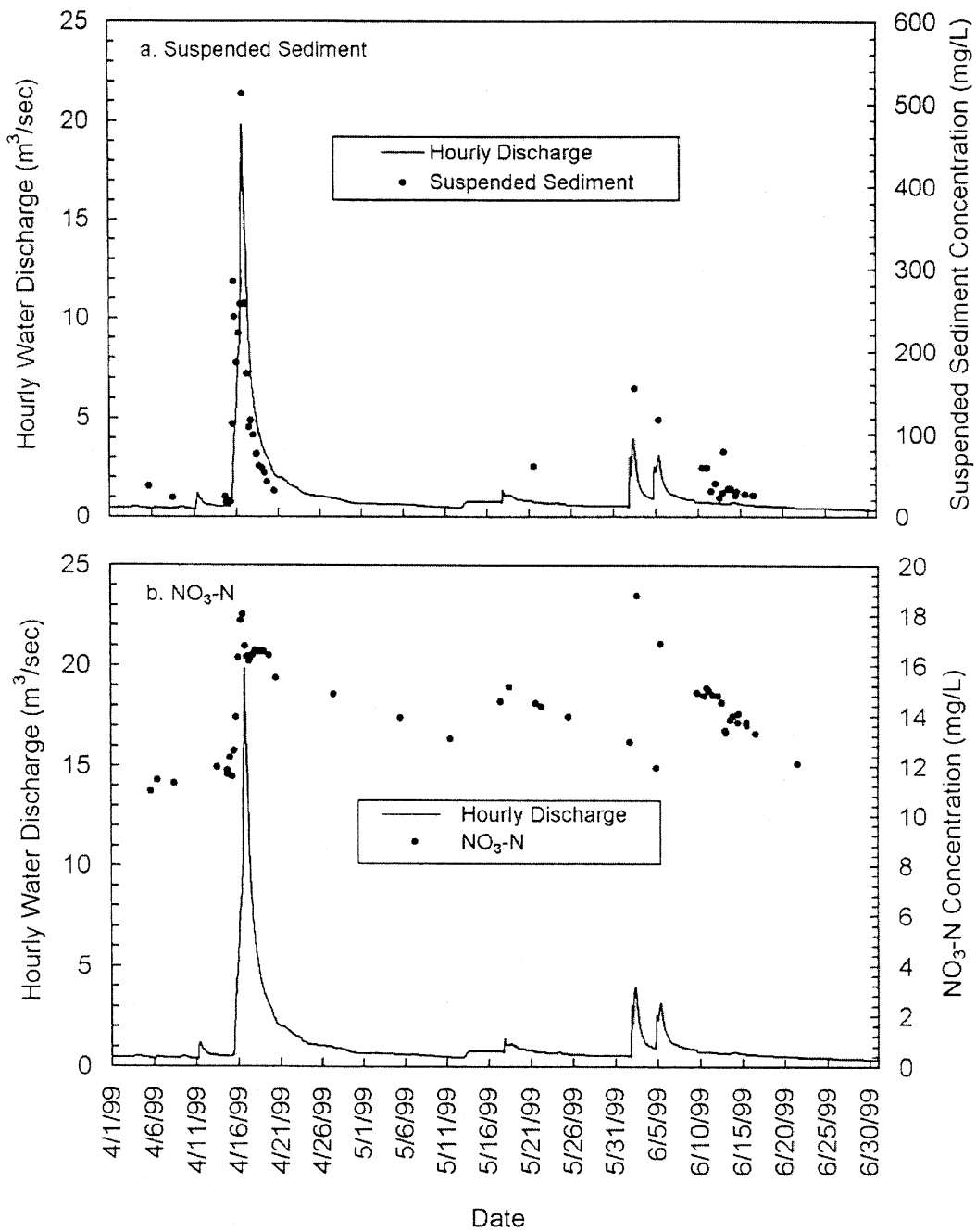

Figure 9. Observed data at Big Ditch monitored during 1999: (a) hydrograph and concentrations of suspended sediment, and (b) hydrograph and concentrations of nitrate-N.

regress well with water discharge for both monthly and combined data $\left(\mathrm{R}^{2}=0.06\right.$ to 0.29$)$. Variation of nitrate-N concentration (fig. 11b) is similar to that of Big Ditch (fig. 9b), but the magnitude is lower, which may again be due to the much larger size of the watershed, with more water for dilution. The nitrate-N concentration fitted similar nearly flat logarithmic functions (positive regression) with water discharge as Big Ditch but with poorer goodness-of-fit $\left(\mathrm{R}^{2}=\right.$ 0.08 to 0.43$)$, except for April $\left(\mathrm{R}^{2}=0.75\right)$ when the major storm occurred.

Figure 12 shows concentrations of phosphate-P and atrazine monitored at the Mahomet station. As expected, both constituents followed the hydrograph (monthly $\mathrm{R}^{2}$ for phosphate-P $=0.71$ to 0.95 , and for atrazine $=0.55$ to 0.93 with a power function relationship with water discharge). The maximum atrazine concentration during the April storm was approximately $6 \mu \mathrm{g} / \mathrm{L}$. On 2 June, the concentration increased to $11 \mu \mathrm{g} / \mathrm{L}$.

Grab samples and continuous flow measurements at the Fisher station, draining a $622 \mathrm{~km}^{2}$ subwatershed, showed patterns of the four constituents similar to that of the Mahomet station (Borah et al., 1999). Both are large subwatersheds. However, the peak atrazine concentration during the June storm was $28 \mu \mathrm{g} / \mathrm{L}$, and the April storm concentration was similar to that of Mahomet $(6 \mu \mathrm{g} / \mathrm{L})$. Errors in sampling may be one of many reasons for such a high single-point atrazine concentration in Fisher. Because Mahomet, located $26 \mathrm{~km}$ downstream, has a relatively higher reading $(11 \mu \mathrm{g} / \mathrm{L})$, heavy application of the herbicide may have occurred on the upper part of the watershed, upstream of Fisher and Big Ditch (18 $\mu \mathrm{g} / \mathrm{L})$ (fig. 1), before the June storm. Reduction of concentration, from $28 \mu \mathrm{g} / \mathrm{L}$ to $11 \mu \mathrm{g} / \mathrm{L}$, may have been due to degradation and dilution along the 26-km path.

\section{SumMARY AND CONCLUSIONS}

Flow and concentrations of suspended sediment, nitrate-N, phosphate-P, atrazine, and metolachlor were collected during 1998 spring storms at the Big Ditch station, which drains a $98 \mathrm{~km}^{2}$ subwatershed of the Lake Decatur watershed. During 1999, the same types of data, except metolachlor, were collected at Big Ditch and at two other stations (Fisher and Mahomet, which drain $622 \mathrm{~km}^{2}$ and $932 \mathrm{~km}^{2}$, respectively, of the Upper Sangamon River or Lake Decatur watershed) on the main stem of the Sangamon River. Rainfall data were collected from six newly established raingages: one at Big Ditch during 1998 and 1999, and five 

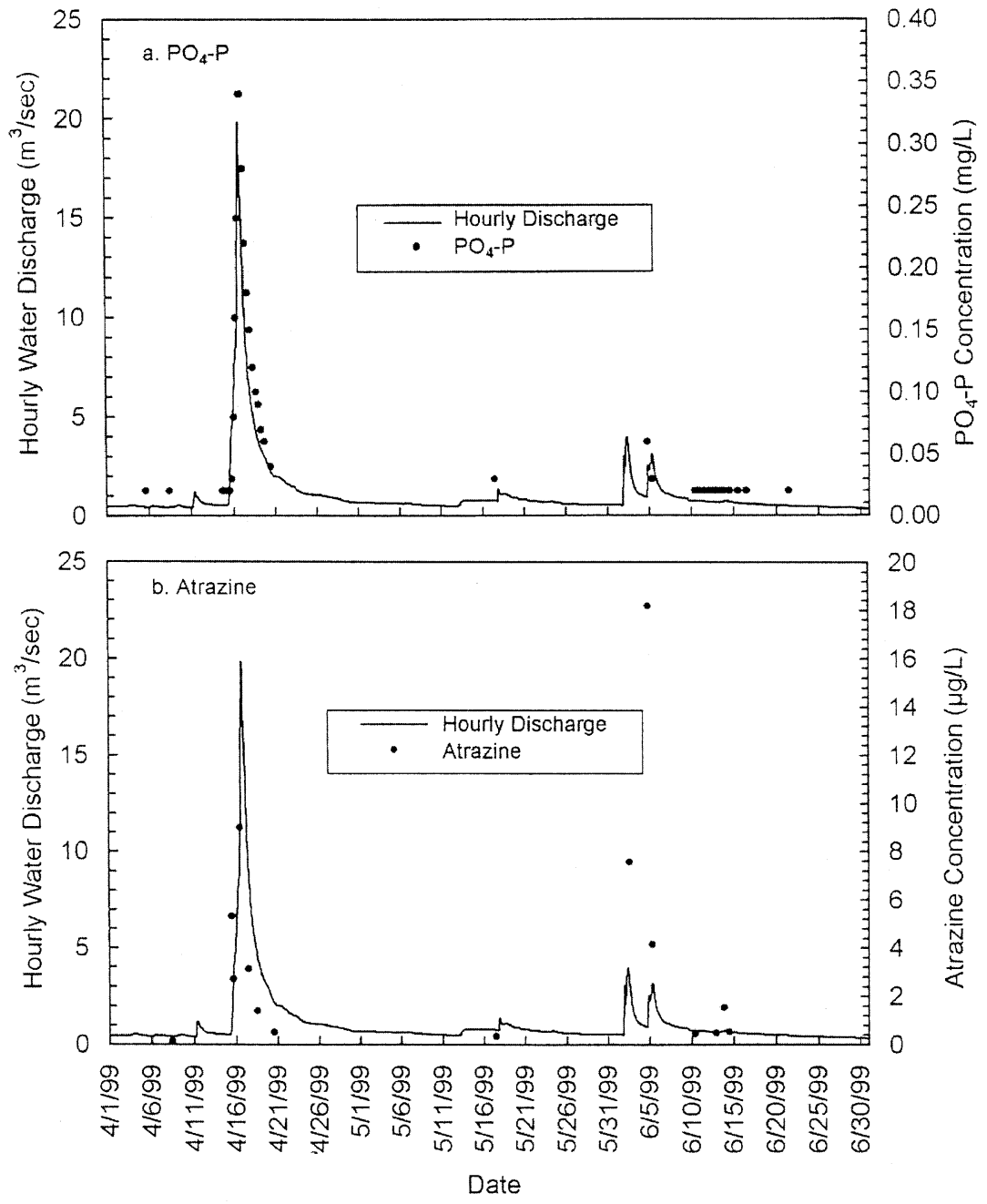

Figure 10. Observed data at Big Ditch monitored during 1999: (a) hydrograph and concentrations of phosphate-P, and (b) hydrograph and concentrations of atrazine.

others throughout the Upper Sangamon River watershed above Mahomet during 1999.

Rainfall data from the six raingage stations showed noticeable variability from station to station, especially between the three eastern and the three western stations. Therefore, a number of raingages recording spatial variations of rainfall are useful to adequately model the watershed and understand the physical and chemical processes and the associated flooding, soil erosion-sedimentation, and water quality problems, which are critical in achieving effective solutions. Further investigation is needed to determine an appropriate number of raingages.

The monitored constituent data from automated collected, grab, and depth-width-integrated samples were analyzed to confirm consistencies of these sampling methods. The data showed good correlation and thus confirmed consistencies of grab and automatic sampling methods while monitoring TSS, nitrate-N, and phosphate-P. Accuracies of TSS concentration data from both grab and automatic sampling were further confirmed using the depth-width-integrated sampling by the DH-59 sampler. These consistencies among the methods may have been because the constituents were well mixed in the stream cross-section during the monitored storm events. More data points with rising, peak, and falling limbs, as well as base flows, are required to confirm consistencies or differences in sampling methods.

The nitrate- $\mathrm{N}$ concentrations in Big Ditch during intense storms of 1998 showed an inverse relationship with water discharge. Higher goodness-of-fit $\left(\mathrm{R}^{2}=0.69\right.$ to 0.79$)$ with exponential decay functions was found for individual months than for the combined data $\left(\mathrm{R}^{2}=0.42\right)$, showing the dependence of nitrate- $\mathrm{N}$ in runoff on varying climate, land cover, and management practices during the growing season. The nitrate- $\mathrm{N}$ concentrations in the Big Ditch and Sangamon River at Fisher and Mahomet during less intense storms in 1999 showed less variability with water discharge, fitting positive logarithmic curves with varying goodness-of-fit $\left(\mathrm{R}^{2}=0.08\right.$ to 0.92$)$ for both monthly and combined data. Results of this study suggest, therefore, that an inverse relation of nitrate- $\mathrm{N}$ concentration with water discharge appears to exist during and between intense rainfall storms early in the growing season.

The total nitrate-N load in Big Ditch generated by the storms of March, May, and June of 1998, a wet year, was similar to the average annual load of $308 \mathrm{t}$ measured between 1993 and 1998. The load from the April, May, and June storms of 1999, a relatively dryer year, was calculated to be $40 \%$ of the average annual load. These numbers indicate that 

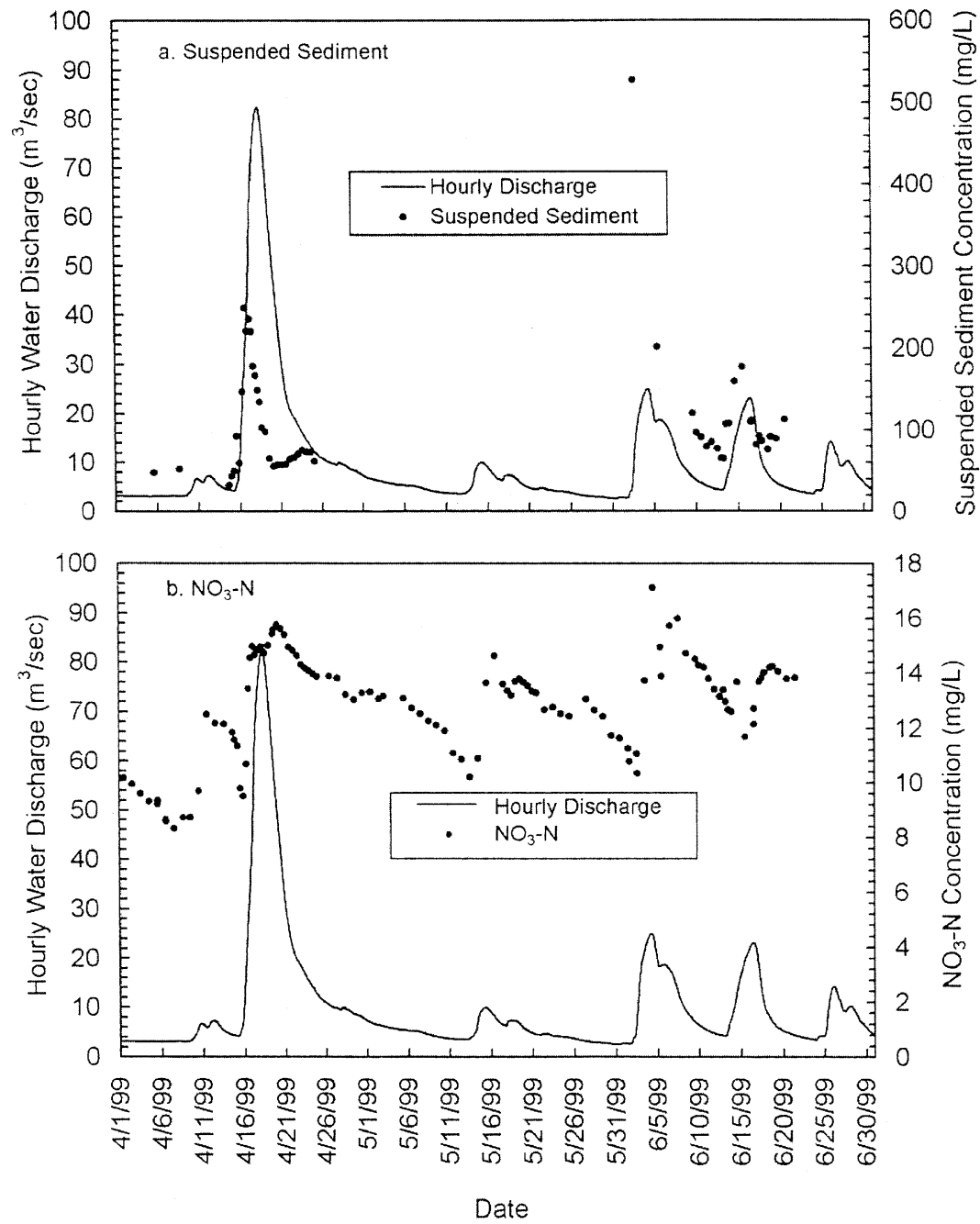

Figure 11. Observed data at Mahomet monitored during 1999: (a) hydrograph and concentrations of suspended sediment, and (b) hydrograph and concentrations of nitrate-N.

storm patterns consisting of severe single-event storms during the year are important and, therefore, deserve close attention.

After a big storm in April 1999, the subsequent small storms during May and June after a long period of low flow resulted in significantly higher nitrate-N concentrations in each of the three stations. A similar pattern was noticed in the 1998 before each of the major peaks, when the smaller peaks elevated nitrate-N concentrations followed by dilution with the larger peaks. These observations agree with those of Arheimer and Liden (2000) for Swedish watersheds. Such a pattern may be due to major storms enriching the pore waters with high nitrate- $\mathrm{N}$ concentrations and smaller storms that do not have enough water for dilution while carrying those nitrate-N rich pore waters to the streams through subsurface and tile drains. Another reason may be the timing of $\mathrm{N}$ application to the soil relative to the occurrence of rainfall events.

The goodness-of-fit $\left(\mathrm{R}^{2}=0.58\right.$ to 0.82$)$ was adequate to reasonably good between suspended sediment concentration and water discharge in the Big Ditch station during both the 1998 (wet) and 1999 (dry) monitoring periods. Relatively better relationships were found for different months than for the combined period, showing the dependence of soil erosion on varying climate, land cover, and management practices during the growing season. Poor relationships $\left(\mathrm{R}^{2}=0.04\right.$ to 0.29) were found in the Sangamon River at Fisher and Mahomet during the 1999 monitoring period. Results of this study, therefore, indicate that the goodness-of-fit between the suspended sediment concentration and water discharge data for the smaller Big Ditch watershed $\left(98 \mathrm{~km}^{2}\right)$ was much better than that of the larger Upper Sangamon River watershed at Fisher $\left(622 \mathrm{~km}^{2}\right)$ or Mahomet $\left(932 \mathrm{~km}^{2}\right)$.

Phosphate-P concentrations showed good relationships $\left(\mathrm{R}^{2}=0.57\right.$ to 0.95$)$ with water discharges at all stations throughout the sampling period. Stronger goodness-of-fit was found for individual months than for combined, indicating dependence on varying conditions and management during the growing season. Atrazine concentrations showed reasonable relationships with water discharges at all stations most of the time $\left(\mathrm{R}^{2}=0.46\right.$ to 0.97$)$. Metolachlor showed good relationships with water discharge during certain months in $1998\left(\mathrm{R}^{2}=0.93\right.$ for May and 0.43 for June). Management practices (e.g., timing of applications) may have been an important factor in the responses of these herbicides.

In this study, monitoring of the larger watersheds (Fisher and Mahomet) was limited to the dryer year of 1999 with less 

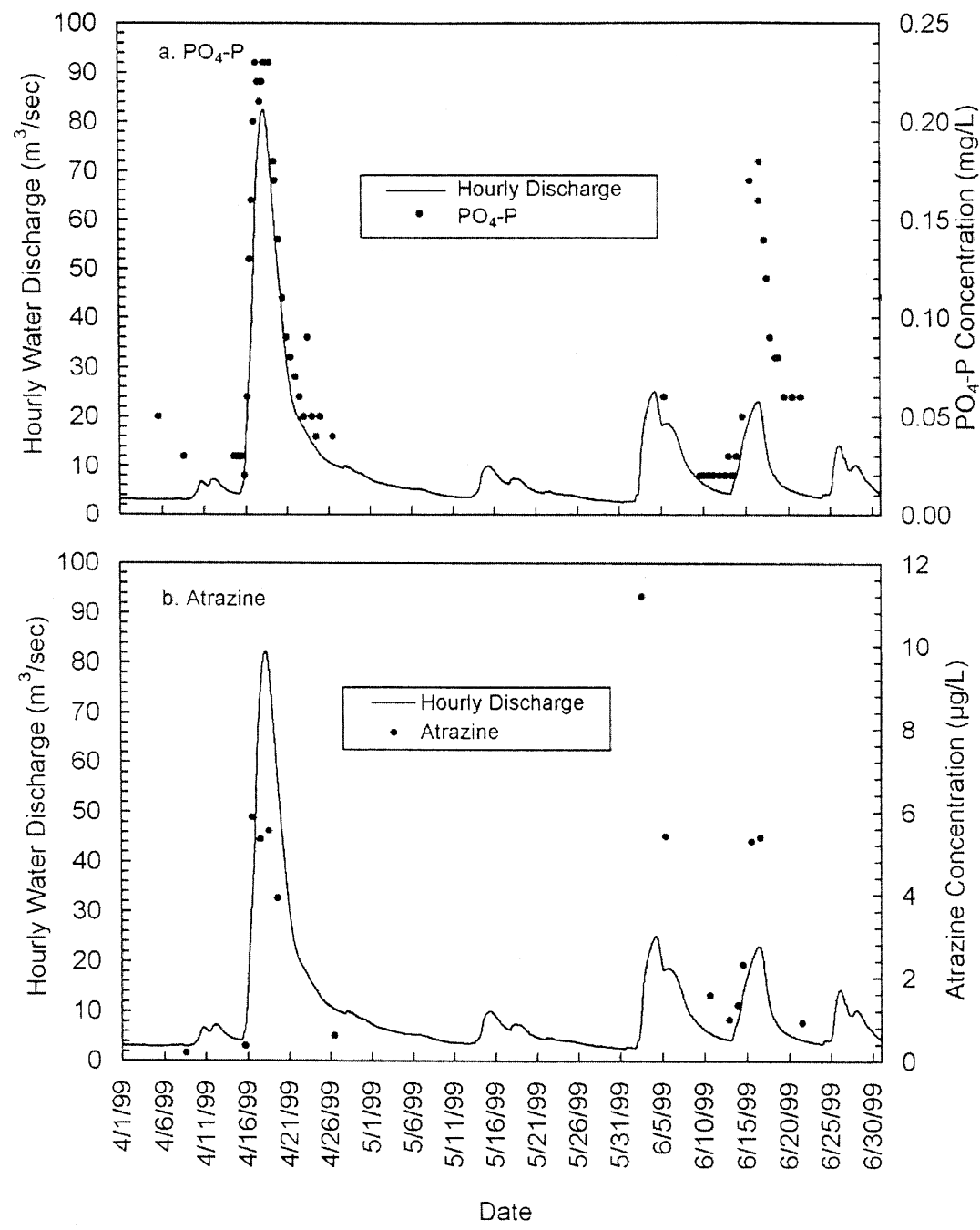

Figure 12. Observed data at Mahomet monitored during 1999: (a) hydrograph and concentrations of phosphate-P, and (b) hydrograph and concentrations of atrazine.

intense storms. Additional monitored data collected during intense and less intense storms from different-sized watersheds, such as Big Ditch and Sangamon River at Fisher, Mahomet, and even Monticello (fig. 1), draining a 1,425 km² basin, would help to provide a better understanding of the processes, their relationships, and their seasonal variations. Detailed understanding of farming practices on the watersheds is essential if the cause and effect relationships between climatic, soil, and land use conditions and water quality are to be identified. For example, timing of fertilizer and herbicide applications with respect to storm occurrences may be a crucial element of storm water quality. Further work is therefore needed to determine the dynamic watershed response of runoff and water quality to specify land management practices under varying climatic conditions.

In addition to the above findings on this east central Illinois watershed, this study provides a valuable database of continuous rainfall, runoff, and concentrations of suspended sediment, nitrate-N, phosphate-P, atrazine, and metolachlor that occur during storm events. The data can be analyzed further to better understand the complex physical and chemical processes that occur in a watershed. The data can also be used to calibrate, validate, and evaluate mathematical models. The flow, sediment, and phosphate-P data moni- tored at the Big Ditch station have already been used to calibrate and validate the hydrologic, sediment, and agrochemical components of the DWSM, a dynamic watershed simulation model. The use of the DWSM or other simulation models could provide valuable information in evaluating land management alternatives to help find solutions to nonpoint-source pollution problems in the Lake Decatur watershed.

\section{ACKNOWLEDGEMENTS}

This article resulted from studies funded by the Illinois Groundwater Consortium (subcontracts 97-03 and 98-06), the Illinois Council on Food and Agricultural Research (contract 01Si-017-5A-WQM), and the Illinois State Water Survey (ISWS). We thank the following ISWS scientists: Misganaw Demissie for his guidance in initial formulation of the study, Laura Keefer for her continued guidance in field data collection, Loretta Skowron and her staff for performing chemical analyses of the monitored water samples, Yi Han for performing sediment analyses of the samples, and finally Edward Krug, Walt Kelly, and Derek Winstanley for reviewing the manuscript and providing useful suggestions. We are also grateful to Michael W. Van Liew, USDA-ARS, El Reno, Oklahoma, and to the three anonymous peer 
reviewers for their thorough review of the manuscript and for providing expert opinions, comments, and valuable suggestions.

\section{REFERENCES}

Arheimer, B., and R. Liden. 2000. Nitrogen and phosphorous concentrations from agricultural catchments?influence of spatial and temporal variables. J. Hydrology 227: 140-159.

Borah, D. K., M. Bera, S. Shaw, and L. Keefer. 1999. Dynamic Modeling and Monitoring of Water, Sediment, Nutrients, and Pesticides in Agricultural Watersheds during Storm Events. Contract Report 655. Champaign, Ill.: Illinois State Water Survey.

Borah, D. K., R. Xia, and M. Bera. 2000. Hydrologic and water quality model for tile drained watersheds in Illinois. Presented at the 2000 ASAE Annual International Meeting. ASAE Paper No. 002093. St. Joseph, Mich.: ASAE.

2001. DWSM - A dynamic watershed simulation model for studying agricultural nonpoint source pollution. Presented at the 2001 ASAE Annual International Meeting. Paper No. 01-2028. St. Joseph, Mich.: ASAE.

Borah, D. K., M. Demissie, and L. L. Keefer. 2002a. AGNPS-based assessment of the impact of BMPs on nitrate-nitrogen discharging into an Illinois water supply lake. Water International 27(2): 255-265.

Borah, D. K., R. Xia, and M. Bera. 2002b. DWSM - A dynamic watershed simulation model. Chapter 5 in Mathematical Models of Small Watershed Hydrology and Applications, 113-166. V. P. Singh and D. K. Frevert, eds. Highlands Ranch, Colo.: Water Resources Publications.

2002c. Watershed model to study hydrology, sediment, and agricultural chemicals in rural watersheds. In: Surface Water Hydrology, 343-358. V. P. Singh, M. Al-Rashed, and M. M. Sherif, eds. Lisse, The Netherlands: A.A. Balkema Publishers.

David, M. B., L. E. Gentry, D. A. Kovacic, and K. M. Smith. 1997. Nitrogen balance in and export from an agricultural watershed. J. Environmental Quality 26(4): 1038-1048.

Demissie, M., and L. Keefer. 1998. Watershed approach for the protection of drinking water supplies in central Illinois. Water International 23(4): 272-277.

Demissie, M., T. W. Soong, and N. G. Bhowmik. 1988. Hydraulic Investigation for the Construction of Artificial Islands in Peoria Lake. ILENR/RE-WR-88/15. Springfield, Ill.: Illinois Department of Energy and Natural Resources.

Demissie, M., L. Keefer, D. Borah, V. Knapp, S. Shaw, K. Nichols, and D. Mayer. 1996. Watershed Monitoring and Land Use Evaluation for the Lake Decatur Watershed. Miscellaneous Publication 169. Champaign, Ill.: Illinois State Water Survey.

Doering, O. C., F. Diaz-Hermelo, C. Howard, R. Heimlich, F. Hitzhusen, R. Kazmierczak, J. Lee, L. Libby, W. Milon, T. Prato, and M. Ribaudo. 1999. Evaluation of economic costs and benefits of methods for reducing nutrient loads to the Gulf of Mexico. Task Group 6 Report, Gulf of Mexico Hypoxia Assessment. Washington, D.C.: White House Committee on Environment and Natural Resources.

Fitzpatrick, W. P., W. C. Bogner, and N. G. Bhowmik. 1985. Sedimentation investigation of Lake Springfield, Springfield, Illinois. Contract Report 363. Champaign, Ill.: Illinois State Water Survey.

1987. Sedimentation and hydrologic processes in Lake Decatur and its watershed. Report of Investigation 107. Champaign, Ill.: Illinois State Water Survey.

Gentry, L. E., M. B. David, K. M. Smith, and D. A. Kovacic. 1998. Nitrogen cycling and tile drainage nitrate loss in a corn/soybean watershed. Agric., Ecosystems, and Environment 68: 85-97.
Goolsby, D. A., W. A. Battaglin, G. B. Lawrence, R. S. Artz, B. T. Aulenbach, R. P. Hooper, D. R. Keeney, and G. J. Stensland. 1999. Flux and sources of nutrients in the

Mississippi-Atchafalaya River Basin. Task Group 3 Report, Gulf of Mexico Hypoxia Assessment. Washington, D.C.: White House Committee on Environment and Natural Resources.

Guy, H. P. 1969. Laboratory theory and methods for sediment analysis. Chapter $\mathrm{C} 1$ in Techniques of Water Resources Investigations of the U.S. Geological Survey, Book 5. Washington, D.C.: U.S. Government Printing Office.

Guy, H. P., and V. W. Norman. 1970. Field methods for measurement of fluvial sediment. Chapter $\mathrm{C} 2$ in Techniques of Water-Resources Investigations of the U.S. Geological Survey, Book 3. Washington, D.C.: U.S. Government Printing Office.

IFMRC. 1994. Sharing the challenge: Floodplain management into the 21st century. Report to the Administration Floodplain Management Task Force. Washington, D.C.: Interagency Floodplain Management Review Committee.

ISCO. 1975. Instruction Manual: Model 1680 Sampler with L.E.D. Readout. Lincoln, Neb.: Instrumentation Specialties Company.

Keefer, L., and M. Demissie. 1999. Watershed monitoring for the Lake Decatur watershed, 1997-1998. Contract Report 637. Champaign, Ill.: Illinois State Water Survey.

Keefer, L., M. Demissie, D. Mayer, K. Nichols, and S. Shaw. 1996. Watershed monitoring and land use evaluation for the Vermilion River watershed. Miscellaneous Publication 176. Champaign, Ill.: Illinois State Water Survey.

Kramer, L. A., M. R. Burkart, D. W. Meek, R. J. Jaquis, and D. E. James. 1999. Field-scale watershed evaluations on deep-loess soils: II. Hydrologic responses to different agricultural land management systems. J. Soil and Water Conservation 54(4): 705-710.

Kumar, B. 2002. Personal communication on 24 March 2002. Roorkee, India: National Institute of Hydrology.

Luepke, M. 1996. Personal communication on 13 September 1996. Springfield, Ill.: City Water Light and Power.

McIsaac, G. 2002. Personal communication on 5 November 2002. Urbana, Ill.: University of Illinois at Urbana-Champaign, Department of Natural Resources and Environmental Sciences.

Mitchell, J. K., G. F. McIsaac, S. E. Walker, and M. C. Hirschi. 2000. Nitrate in river and subsurface drainage flows from an east central Illinois watershed. Trans. ASAE 43(2): 337-342.

Roberts, B. 2002. Personal communication on 4 November 2002. Champaign, Ill.: USDA-Natural Resources Conservation Service (NRCS).

Robertson, D. M., and E. D. Roerish. 1999. Influence of various water quality sampling strategies on load estimates for small streams. Water Resources Research 35(12): 3747-3759.

Roseboom, D., R. L. Evans, J. Erickson, and L. G. Brooks. 1982. An inventory of Court Creek watershed characteristics that may relate to water quality in the watershed. Contract Report 322. Peoria, Ill.: Illinois State Water Survey.

Shirmohammadi, A., K. S. Yoon, and W. L. Magette. 1997. Water quality in mixed land-use watershed - Piedmont region in Maryland. Trans. ASAE 40(6): 1563-1572.

Smith, R. A., R. B. Alexander, and K. J. Lanfear. 1993. Stream water quality in the conterminous United States: Status and trends of selected indicators during the 1980s. In National Water Summary 1990-91: Hydrologic Events and Stream Water Quality, 111-140. USGS Water Supply Paper 2400. Washington, D.C.: U.S. Geological Survey.

Stone, K. C., P. G. Hunt, J. M. Novak, M. H. Johnson, and D. W. Watts. 2000. Flow-proportional, time-composited, and grab sample estimation of nitrogen export from an eastern coastal plain watershed. Trans. ASAE 43(2): 281-290.

USEPA. 1983. Methods of chemical analysis of water and wastes. EPA-600/4-79-020 Cincinnati, Ohio: USEPA, NERL-Cincinnati. 
1991. Methods for the determination of organic compounds in drinking water. EPA/600/4-88/039. Cincinnati, Ohio: USEPA.

1993. Methods for the determination of inorganic substances in environmental samples. EPA-600/R-93-100 Cincinnati, Ohio: USEPA.
Young, R. A., C. A. Onstad, D. D. Bosch, and W. P. Anderson. 1987. AGNPS, Agricultural nonpoint source pollution model: A watershed analytical tool. USDA Conservation Research Report 35. Washington, D.C.: USDA Agricultural Research Service. 